University of Wollongong

Research Online

Faculty of Engineering - Papers (Archive)

Faculty of Engineering and Information

Sciences

October 2007

\title{
Stabilisation of granular media and formation soil using geosynthetics with special reference to railway engineering
}

\author{
Buddhima Indraratna \\ University of Wollongong, indra@uow.edu.au \\ Mohamed A. Shahin \\ Curtin University, shahin@uow.edu.au \\ Wadud Salim \\ University of Wollongong, wadud@uow.edu.au
}

Follow this and additional works at: https://ro.uow.edu.au/engpapers

Part of the Engineering Commons

https://ro.uow.edu.au/engpapers/399

\section{Recommended Citation}

Indraratna, Buddhima; Shahin, Mohamed A.; and Salim, Wadud: Stabilisation of granular media and formation soil using geosynthetics with special reference to railway engineering 2007.

https://ro.uow.edu.au/engpapers/399

Research Online is the open access institutional repository for the University of Wollongong. For further information contact the UOW Library: research-pubs@uow.edu.au 


\title{
Stabilisation of granular media and formation soil using geosynthetics with special reference to railway engineering
}

\author{
B. INDRARATNA*, M. A. SHAHIN* and W. SALIM ${ }^{\dagger}$ \\ ${ }^{*}$ Faculty of Engineering, University of Wollongong, Australia ${ }^{\dagger}$ RailCorp, Sydney, Australia
}

\begin{abstract}
Railway ballast breaks down and deteriorates progressively under train cyclic loading, and soft formation soil fails due to repetitive stress, leading to costly rail track maintenance. Using geosynthetics, track conditions can be improved and maintenance costs can be reduced. This paper addresses the potential use of geosynthetics for improving the deformation characteristics of rail ballast and formation soil. The prospective use of different types of geosynthetics was investigated using a large-scale prismoidal triaxial rig, and a plane strain finite element analysis (PLAXIS) of the rig was carried out to obtain the optimum location of geosynthetics in rail track substructure. A large-scale consolidometer was also employed to determine the effect of prefabricated vertical drains (PVDs) in optimising the accelerated primary consolidation of track soft formation. This paper also includes a section where recommendations are made on how to prepare the stability of rail tracks on surface formation soils considerably disturbed/remoulded by the Asian tsunami in Sri Lanka. The research findings reveal that geosynthetics have a good potential for resilient track construction and for reducing the cost of track maintenance.
\end{abstract}

Keywords: geosynthetics; prefabricated vertical drains (PVDs); rail track; soil stabilisation
Le ballast d'infrastructure ferroviaire se fracture et se détériore progressivement sous le chargement cyclique des trains et le sol de formation molle se fracture en raison de la charge répétée. Ces dégradations sont à l'origine d'une maintenance coûteuse des voies ferrées. Les conditions de ces infrastructures peuvent s'améliorer et le coût de leur maintenance diminuer grâce à l'utilisation de la géosynthétique. Cet article illustre l'application potentielle de la géosynthétique pour l'amélioration des caractéristiques de déformation du ballast des voies ferroviaires et du sol de formation. L'utilisation prospective de différents types de géosynthétique est étudiée au moyen d'un montage triaxial prismoïde et une analyse en éléments finis en déformation plane (PLAXIS) du montage est réalisée pour obtenir l'emplacement optimal de la géosynthétique au niveau de la sous-structure de la voie ferrée. Un consolidomètre de grande échelle a également permis de déterminer le rôle des drains verticaux préfabriqués (DVP) dans l'optimisation de la consolidation primaire accélérée de la formation molle de la voie. L'article présente également une section comportant des recommandations sur les moyens de préparer la stabilité des voies ferrées sur le sols de formation en surface considérablement perturbés / remodelés par le tsunami asiatique qui a touché le Sri Lanka. Les résultats de ces travaux indiquent que la géosynthétique se révèle prometteuse en termes de construction de voies ferrées élastiques et de réduction des coûts de maintenance des voies.

\section{Introduction}

Rail tracks are conventionally founded on compacted ballast platforms, which are laid on natural or improved subsoil. The deviation of track alignment and vertical profile from the design geometry due to progressive degradation of ballast and consolidation of soft formation often invokes costly track maintenance. In order to compete with other modes of transportation, rail authorities are under tremendous pressure to minimise track maintenance cost, and to find alternative materials and approaches to improve the performance of rail tracks. In order to improve the track conditions

and to reduce maintenance cost, the use of geosynthetics in the form of the following methods can be considered:

(a) insertion of geosynthetics at the ballast/capping interface to increase the effective bearing capacity of the subgrade, and also provide filtration, separation and better drainage for the ballast layer

(b) inclusion of suitable types of geosynthetics with selected waste ballast (after cleaning) instead of replacing by fresh ballast during maintenance

(c) use of prefabricated vertical drains (PVDs) to accelerate the consolidation process of soft formation soils.

In order to investigate the potential and effectiveness of these methods, a comprehensive research programme was launched at the University of Wollongong (UoW), sponsored 
by the Cooperative Research Centre for Railway Engineering and Technologies (RAIL-CRC), Australia. In this study, the prospective use of three types of geosynthetics (geogrids, geotextiles and geocomposites) in enhancing the performance of ballast was examined. The aspects of deformation and degradation of ballast under cyclic loading were studied using a large-scale cylindrical triaxial apparatus, and the prospective use of geosynthetics in improving ballast performance was investigated using a large-scale prismoidal triaxial rig. A plane-strain finite element numerical model that utilises the code PLAXIS was developed to simulate rail track substructure in the prismoidal triaxial rig and was used to obtain the optimum location of geosynthetics in rail tracks. Furthermore, a large-scale consolidometer that has been fabricated and installed at UoW was used to determine the effect of prefabricated vertical drains in optimising the accelerated consolidation process of the soft formation soil of the rail track.

\section{Applications of geosynthetics in rail tracks}

A wide variety of geosynthetics with different properties have been developed to meet highly specific requirements corresponding to a range of different uses. Naturally, the railway authorities have not been indifferent to these developments. The structure of the rail system (ballast laid on a hard core base, itself resting on underlying soils) makes it an ideal candidate for such products. Geosynthetics have been used in various ways in new rail tracks and track rehabilitation for almost three decades. In new tracks, the geosynthetics are installed directly on the formation or capping layer (Raymond, 2002). In track rehabilitation, they are installed on top of old ballast, which has either been trimmed or embedded in the original subgrade formation (Ashpiz et al., 2002). There are several problems required to be rectified in railway tracks: increasing the bearing capacity of the subgrade soil; preventing the contamination of ballast with subgrade fines; and dissipation of high pore water pressures built up by cyclic train loading. When appropriately designed and installed, geosynthetics provide a costeffective alternative solution to more traditional techniques.

A general study on railway rehabilitation was conducted in North America by Raymond (1999), who performed several experiments with different geotextiles placed under ballast. The main result of the investigation was that all geotextiles with a weight (mass per unit area) lower than $500 \mathrm{~g} / \mathrm{m}^{2}$ had failed after 5 years of installation. Raymond (1999) concluded that, if the product fulfilled this specification and was also correctly installed, its behaviour would be satisfactory. He also found that geotextiles installed even without a capping sand layer, but meeting the given specification, still embrace excellent durability. He concluded that the greatest application of geosynthetics was in poorly drained regions of the terrain that were flat and possibly marshy.

Enhancing the performance of rail tracks by composite geosynthetics is now seriously considered by the rail industry. As Rowe and Jones (2000) have described, geocomposites can provide reinforcement to the ballast layer, as well as filtration and separation functions simultaneously. The combination of geotextiles and geogrids is considered to maximise the benefits to the railway tracks in the following ways: geogrids to provide tensile reinforcement and shear resistance to increase the effective bearing capacity of the subgrade, and also to interlock with the ballast and increase its resistance to both vertical and lateral movement; and geotextiles for separation and filtration, preventing contamination of the ballast and providing quick relief of pore water pressures. Based on relatively low cost and the proven performance of geosynthetics in various railway applications, the authors have conducted wide-ranging research to investigate the effects of different types of geosynthetics on fresh ballast, recycled ballast, track drainage and stabilisation of railway formation, as will be described later.

\section{Geotechnical behaviour of ballast}

Ballast is a free-draining granular material used as a loadbearing material in railway tracks. It is composed of medium to coarse gravel-sized aggregates $(10-60 \mathrm{~mm})$ with a small percentage of cobble-sized particles. Ballasted tracks are still the most common railroad structure, owing to the relatively low cost of construction and possibility of maintenance (Janardhanam and Desai, 1983; Jeffs and Marich, 1987; Indraratna et al., 2003). The thickness of ballast should be such that the subgrade is loaded as uniformly possible. The optimum thickness is usually $250-350 \mathrm{~mm}$ measured from the lower side of the sleeper. Good-quality railway ballast should have angular particles, high specific gravity, high shear strength, high toughness and hardness, high resistance to weathering, a rough surface, and minimum hairline cracks. However, the sources of high-quality ballast are limited, and under dynamic loading conditions most ballast properties change progressively because of breakage, deformation and fouling. Fouling of ballast decreases its permeability, and therefore causes hydraulic erosion and reduction in stability because of the delay in dissipation of excess pore water pressures.

The main functions of ballast are to distribute the loads received from the sleepers, to damp dynamic loads, and to provide lateral resistance and rapid drainage. The ballast characteristics required for these functions are clearly contradictory in some aspects, and thus a particular type of ballast cannot accomplish all of them completely. It could be argued that, for high load-bearing characteristics and maximum track stability, ballast needs to be angular, well graded, and compact, which in turn reduces the drainage of the rail track. Therefore a balance needs to be achieved between the bearing capacity and drainage. To elucidate this point, the main geotechnical properties of ballast are briefly discussed in this part, and it will be shown later in this paper that the use of geosynthetics with special characteristics in the track bed may supplement or further improve the various functions that ballast is required to perform.

\section{Shear strength}

Conventionally, the shear strength of granular materials is assumed to vary linearly with the applied stress, and MohrCoulomb theory is usually used to describe the conventional shear behaviour. However, research by Indraratna et al. (1993) and Ramamurthy (2001), among others, has shown that, when soils at high stresses and rocks at low normal stresses are tested, a non-linear shear strength response is obtained. Hence one set of values of cohesion intercept $c$ and the angle of shearing resistance $\phi$ cannot be used to accurately represent the failure envelopes corresponding to the entire range of stresses. Indraratna et al. (1993) proposed a non-linear strength envelope obtained during the testing of granular media at low normal stress. This non-linear shear stress envelope is represented by 


$$
\frac{\tau_{\mathrm{f}}}{\sigma_{\mathrm{c}}}=m\left(\frac{\sigma_{\mathrm{n}}^{\prime}}{\sigma_{\mathrm{c}}}\right)^{n}
$$

where $\sigma_{\mathrm{c}}$ is the uniaxial compressive stress of the parent rock determined from the point load test, $m$ and $n$ are dimensionless constants, $\tau_{\mathrm{f}}$ is the shear stress at failure, and $\sigma_{\mathrm{n}}^{\prime}$ is the effective normal stress. The non-linearity of the stress envelope is governed by the coefficient $n$. For small confining pressures (below $200 \mathrm{kPa}$ ) representative of rail tracks, $n$ takes values in the order of 0.65-0.75. A large-scale cylindrical triaxial apparatus, which could accommodate specimens $300 \mathrm{~mm}$ in diameter and $600 \mathrm{~mm}$ high (Fig. 1), was used by Indraratna et al. (1998) to verify equation (1). The results of that study associated with latite basalt in a normalised form are plotted in Fig. 2, with other results obtained for various sources of basalt.

\section{Ballast degradation and quantification of particle breakage}

The main causes of ballast degradation are excessive cyclic loading and vibration, temperature and moisture fluctuation,

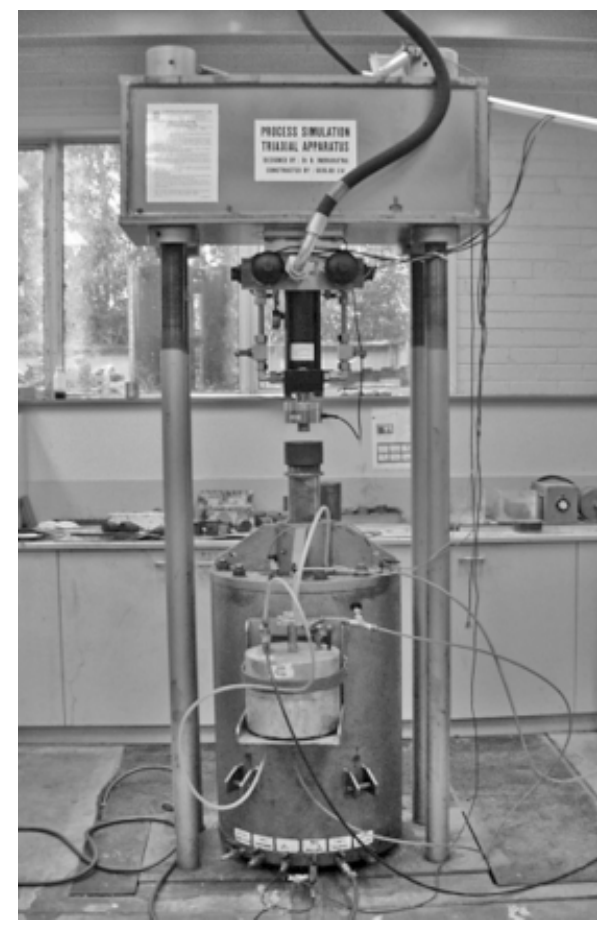

Fig. I. Cylindrical triaxial apparatus with dynamic actuator designed at the University of Wollongong

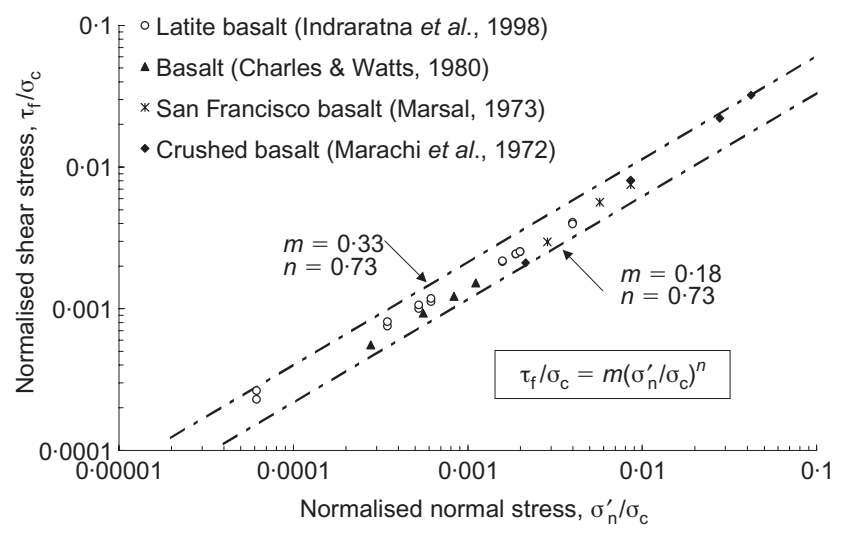

Fig. 2. Normalised shear stress for basalt aggregates (Indraratna et al., 1998) as well as impact load on ballast due to severe braking. The degradation of ballast particles can occur in three ways:

(a) grinding-off of small-scale asperities (abrasion), in which resulting fines cause fouling and reduce drainage

(b) breaking of fragments and angular projections, which influence the initial settlement

(c) fracturing or splitting of individual particles.

This breakage is responsible for the long-term stability and safety of the track. Experimental investigations (Hardin, 1985; Lade et al., 1996; Indraratna et al., 2003) have shown that the potential for particle breakage increases with ballast size. This is because larger particles contain more flaws. Smaller particles are generally produced from larger particles fracturing along their defects. Therefore smaller particles are less likely to fracture, as they contain fewer defects. Increasing particle angularity increases particle breakage. Angular particles break more easily because stresses can concentrate along their narrow dimension or angular contact points, thus breaking the particle. Both monotonic tests (Marsal, 1967) and cyclic tests (Indraratna et al., 2000, 2003) on ballast specimens have indicated that well-graded samples do not break as easily as uniform ones, and that higher relative density reduces the amount of particle breakage. This is because, with more particles surrounding each particle, the average contact stress tends to decrease. The degradation of ballast under loading has been observed in both wet and dry conditions (Indraratna and Salim, 2003). Ballast experiences significant particle breakage upon saturation. Furthermore, the rate of particle breakage normally increases with increasing confining pressure. However, the effect of low confining pressure on ballast degradation has yet to be examined under cyclic loading. Generally, the main factors that affect ballast breakage can be divided into three categories:

(a) ballast properties related to the characteristics of the parent rock (e.g. hardness, specific gravity, toughness, weathering, mineralogical composition, internal bonding and grain texture)

(b) physical properties associated with individual particles (e.g. soundness, durability, particle shape, size, angularity and surface smoothness)

(c) factors related to the assembly of particles and loading conditions (e.g. confining pressure, initial density or porosity, thickness of ballast layer, ballast gradation, presence of water or ballast moisture content, cyclic loading pattern including load amplitude and frequency).

Various particle breakage indices have been proposed to quantify the amount of particle breakage. These breakage indices are empirical in nature, and are based on changes in particle sizes as the key measurement. In other words, the amount of particle breakage during loading of a soil sample is defined by the particle size distribution curves measured before and after loading. In general, the various techniques for quantification of particle breakage can be divided into the following two categories:

(a) breakage factor based on increase in percentage passing a single sieve size (Lee and Farhoomand, 1967; Leslie, 1975; Lade et al., 1996; Nakata et al., 1999)

(b) breakage factor based on changes in the entire particle size distribution (Marsal, 1967; Miura and O'Hara, 1979; Hardin, 1985).

In order to evaluate the ballast breakage, the second 
category, in which the degradation of all particles is taken into consideration, is recommended by railway researchers (Indraratna and Salim, 2002). Miura and O'Hara (1979) found that the increase in surface area of particles after the test would be a reasonable measure for describing the amount of particle crushing quantitatively. Hardin (1985) also defined three measures of particle breakage that are based on changes in the entire particle size distribution: breakage potential, total breakage and relative breakage. The breakage potential was defined as the area between the original grain size distribution curve of soil and the sieve size, $0.074 \mathrm{~mm}$. The total breakage was specified as the area between the original and final particle size distribution curves. The relative breakage (a factor between zero and unity) was defined as the ratio of the total breakage to the potential breakage. Marsal (1967) developed a measure of particle breakage in connection with the construction and design of earth and rockfill dams. His method involves individual particle sizes between the initial and final particle size distributions. Marsal's breakage index $B_{\mathrm{g}}$ is the sum of the difference in percentage retained on sieves, having the same sign. This particle breakage index is adopted in this study to quantify the degradation of aggregates, because of its simplicity and reliability.

\section{Constitutive modelling of ballast}

The degree of particle breakage affects the strength characteristics of ballast. Salim and Indraratna (2004) developed a continuum-mechanics-based constitutive model incorporating dilatancy and plastic flow rule to predict particle breakage. They used a generalised $3 \mathrm{D}$ system to define contact forces, stresses and strains in granular media including the plastic potential, hardening function and particle breakage. The model is based on the critical state concept and the theory of plasticity with a kinematic-type yield locus (constant stress ratio). The increments of plastic distortional strain $\mathrm{d} \varepsilon_{\mathrm{S}}^{\mathrm{p}}$ and volumetric strain $\mathrm{d} \varepsilon_{\mathrm{V}}^{\mathrm{p}}$ were given by Salim and Indraratna (2004) as follows.

$$
\mathrm{d} \varepsilon_{\mathrm{s}}^{\mathrm{p}}=\frac{2 \alpha \kappa\left(\frac{p}{p_{\mathrm{cs}}}\right)\left(1-\frac{p_{\mathrm{o}(\mathrm{i})}}{p_{\mathrm{cs}(\mathrm{i})}}\right)\left(9+3 M-2 \eta^{*} M\right) \eta \mathrm{d} \eta}{M^{2}\left(1+e_{\mathrm{i}}\right)\left(\frac{2 p_{\mathrm{o}}}{p}-1\right)\left\{9\left(M-\eta^{*}\right)+\frac{B}{p}\left[\chi+\mu\left(M-\eta^{*}\right)\right]\right\}}
$$

$$
\mathrm{d} \varepsilon_{\mathrm{v}}^{\mathrm{p}}=\frac{9(M-\eta)}{9+3 M-2 \eta^{*} M} \mathrm{~d} \varepsilon_{\mathrm{s}}^{\mathrm{p}}+\left(\frac{B}{p}\right)\left[\frac{\chi+\mu\left(M-\eta^{*}\right)}{9+3 M-2 \eta^{*} M}\right] \mathrm{d} \varepsilon_{\mathrm{s}}^{\mathrm{p}}
$$

where $p$ is the effective mean stress, $p_{\mathrm{cs}}$ is the value of $p$ on

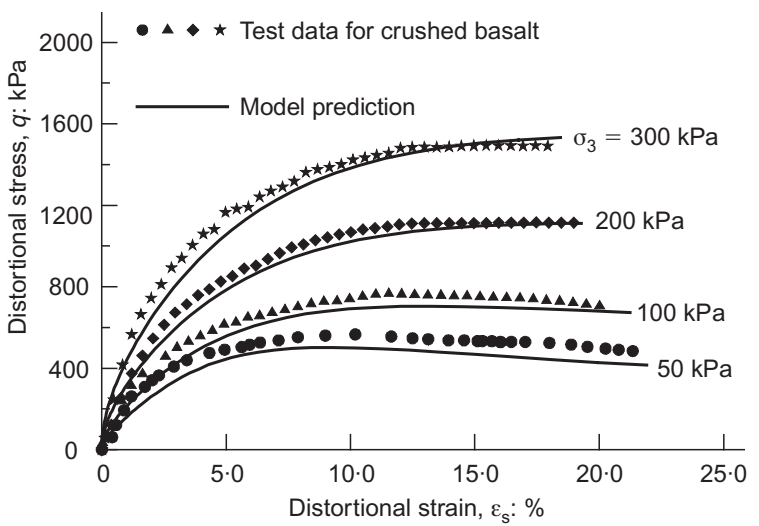

(a) the critical state line at the current void ratio, $p_{\mathrm{o}}$ is the value of $p$ at the intersection of the undrained stress path and the initial stress line, and subscript $i$ indicates the initial value at the start of shearing; $\eta$ is the stress ratio $(\eta=q / p), q$ is the deviator stress, and $\eta^{*}=\eta\left(p / p_{\mathrm{cs}}\right) ; M$ is the critical state stress ratio; $e_{\mathrm{i}}$ is the initial void ratio; $\kappa$ is the negative slope of the compression curve $(e-\ln p) ; \alpha$ and $B$ are two dimensionless constants; and $\chi$ and $\mu$ are the material constants defining the rate of particle breakage. This model was verified using large-scale triaxial laboratory results (Fig. 3). The above constitutive model contains 11 parameters, which can be evaluated using drained triaxial test results alongside the particle breakage measurements. Salim (2004) has recently extended the above principles to capture surface bonding plasticity under cyclic loading.

\section{Effect of particle size distribution}

The ballast particle size distributions currently employed for railway lines are very uniform and contain only a small percentage of fine particles (particles less than $20 \mathrm{~mm}$ ). Although several benefits of better-graded distributions have been identified, for example superior strength and reduced settlement (Raymond, 1985; Jeffs and Marich, 1987), they are rarely employed because of the reduced drainage capacity and increased fouling risk. In order to evaluate how slight changes in particle size distribution can affect the deformation and degradation behaviour of ballast, large-scale cyclic triaxial tests were conducted on four different distributions of latite basalt (Indraratna et al., 2004), a type of ballast commonly used in New South Wales, Australia. Details of the testing apparatus, shown in Fig. 1, can be found in Indraratna et al. (2003). It is known that well-graded aggregates can be compacted to higher densities than uniform specimens. Therefore, in order to mimic field conditions as closely as possible, specimens were compacted to equivalent heights using a fixed compaction time: thus specimens varied in initial density and void ratio. The gradation and void ratio characteristics of the test specimens are shown in Fig. 4. Samples were subjected to an effective confining pressure of approximately $45 \mathrm{kPa}$ to mimic the low in situ pressures encountered beneath railway tracks. To simulate moderate train weights travelling at high speed, loading was applied cyclically at a frequency of $20 \mathrm{~Hz}$ up to a maximum deviator stress $q_{\max }$ of $300 \mathrm{kPa}$. Fig. 5 shows the effect of particle size distribution on axial and volumetric strain behaviour during drained cyclic loading. The very uniform and uniform samples exhibit higher axial and volumetric strains, which is due largely to their looser states prior to cyclic shear. The gap-graded and moderately graded

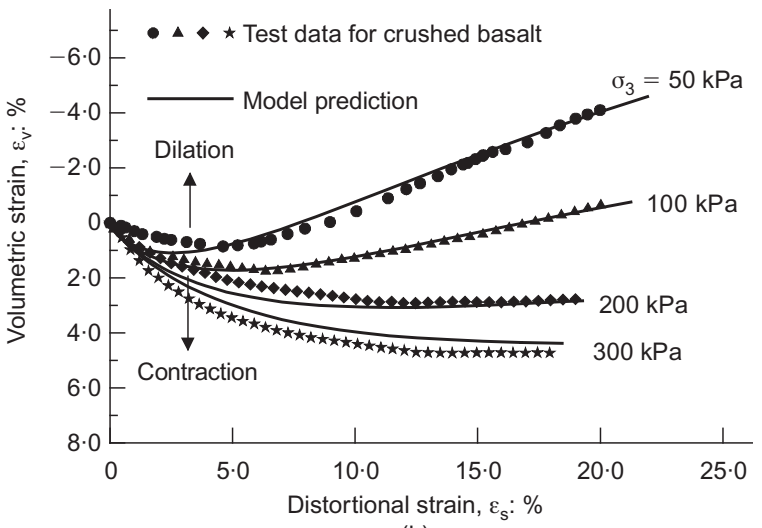

(b)

Fig. 3. Model predictions compared with experimental data for drained triaxial shearing (Salim and Indraratna, 2004) 


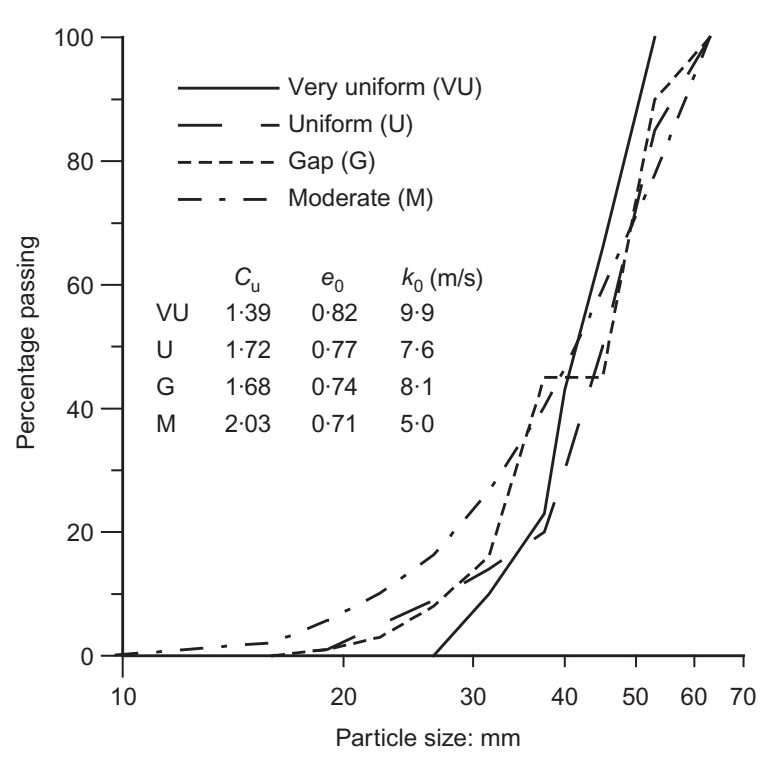

Fig. 4. Particle size distributions and ballast properties used in the triaxial tests (Indraratna et al., 2004)

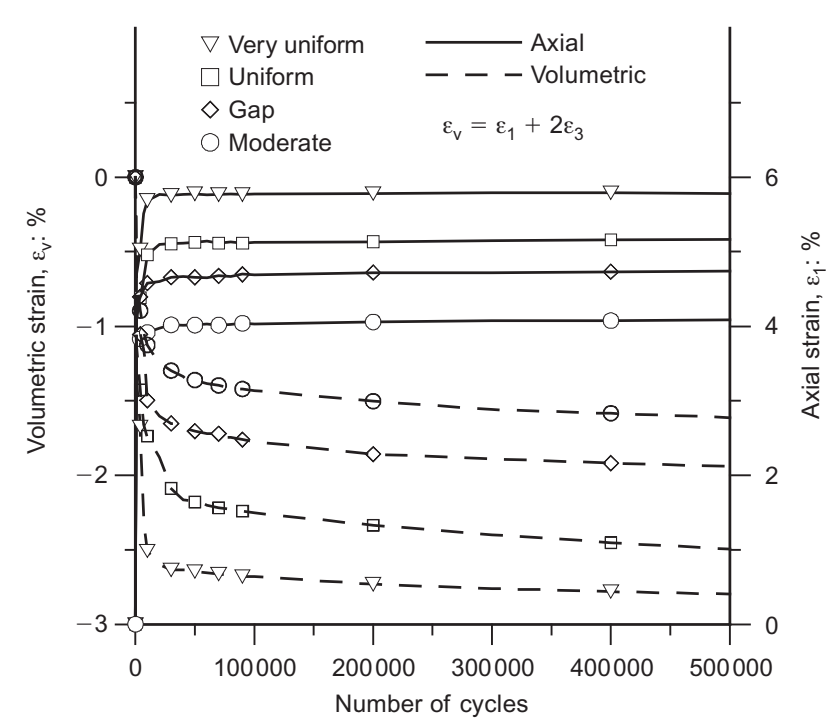

Fig. 5. Axial and volumetric strain response of different distributions under cyclic loading (Indraratna et al., 2004)

distributions form denser particle arrangements with a greater coordination number, and if either of these distributions were utilised in the field, the track structure would experience decreased settlement and greater shear strength. Fig. 6 shows the relationship between the initial $C_{u}$ (coefficient of uniformity) and particle breakage. With the exception of the gap-graded specimen, as $C_{\mathrm{u}}$ increases there is a decrease in the amount of particle degradation. The gapgraded distribution excludes particle sizes that have been found to be vulnerable to breakage in past studies (Indraratna et al., 2001), and shows lower breakage than the uniform and very uniform gradations (Fig. 6).

As Fig. 4 shows, the initial permeability $k_{0}$ according to Hazen's formula (Hazen, 1930) would drop by approximately $50 \%$ if the moderately graded distribution were employed instead of the very uniform distribution. However, in the absence of fouling, the moderately graded ballast is still highly free draining, and in terms of degradation,

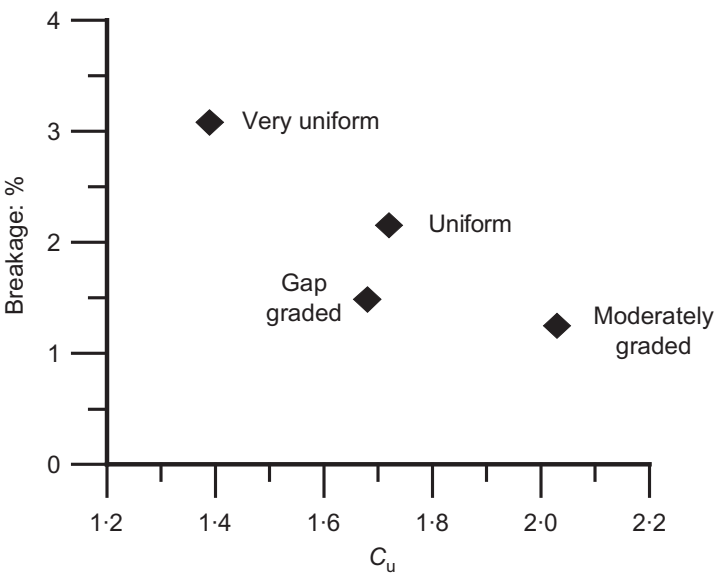

Fig. 6. Effect of grading on particle breakage (Indraratna et al., 2004)

settlement and strength is far superior to current ballast grading specifications. The test results for ballast with varying gradation indicate that even modest changes in $C_{u}$ can substantially affect strain and breakage behaviour, and that a distribution similar to the moderate grading would give improved track performance. Accordingly, the authors recommend using a modified particle size distribution range for railway ballast with a $C_{\mathrm{u}}$ equal to or slightly greater than 2. This new ballast particle size distribution, which is slightly better graded than the current ballast grading of Australian standards (Standards Australia, 1996), is shown in Fig. 7.

\section{Effect of confining pressure}

Although the effective confining pressure is considered to be one of the key criteria in various design procedures in geotechnical engineering, it is not taken as a significant factor in conventional rail track design. The rail track substructure is essentially self-supporting with minimal lateral constraint. During train passage, ballast and capping materials are free to spread laterally, contributing to increased track settlement and decreased shear strength. At the University of Wollongong, cyclic triaxial tests have been conducted on ballast samples to investigate the effect of confining pressure on ballast behaviour. The testing proce-

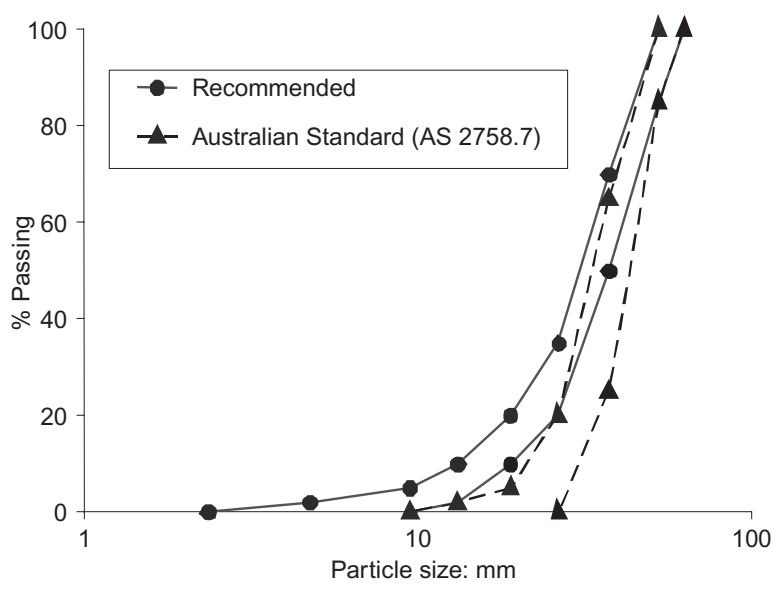

Fig. 7. Recommended railway ballast grading in comparison with current Australian Standard grading requirements (Indraratna et al., 2004) 
dure was similar to that outlined for the particle size distribution tests. Specimens were prepared with the same gradation and initial porosity (i.e. $d_{50}=38.5 \mathrm{~mm}, C_{\mathrm{u}}=1.54$ and $\left.e_{0}=0.76\right)$. Effective confining pressures $\left(\sigma_{3}^{\prime}\right)$ ranged from 1 to $240 \mathrm{kPa}$ with $q_{\max }=230 \mathrm{kPa}$. Fig. 8 shows the relationship between axial strain $\left(\varepsilon_{1}\right)$ and volumetric strain $\left(\varepsilon_{\mathrm{v}}\right)$ as a function of $\sigma_{3}^{\prime}$. As expected, increasing $\sigma_{3}^{\prime}$ leads to a decrease in $\varepsilon_{1}$. Volumetric strain behaviour changes from dilation towards compression with an increase in $\sigma_{3}^{\prime}$. Under static loading at low $\sigma_{3}^{\prime}$, coarse materials will first compress and then begin to dilate. However, under cyclic loading, samples that dilate significantly do not usually show an initial period of compression.

The effect of $\sigma_{3}^{\prime}$ on particle degradation is shown in Fig. 9, where sample breakage behaviour has been divided into three regions: (I) dilatant unstable, (II) optimum and (III)

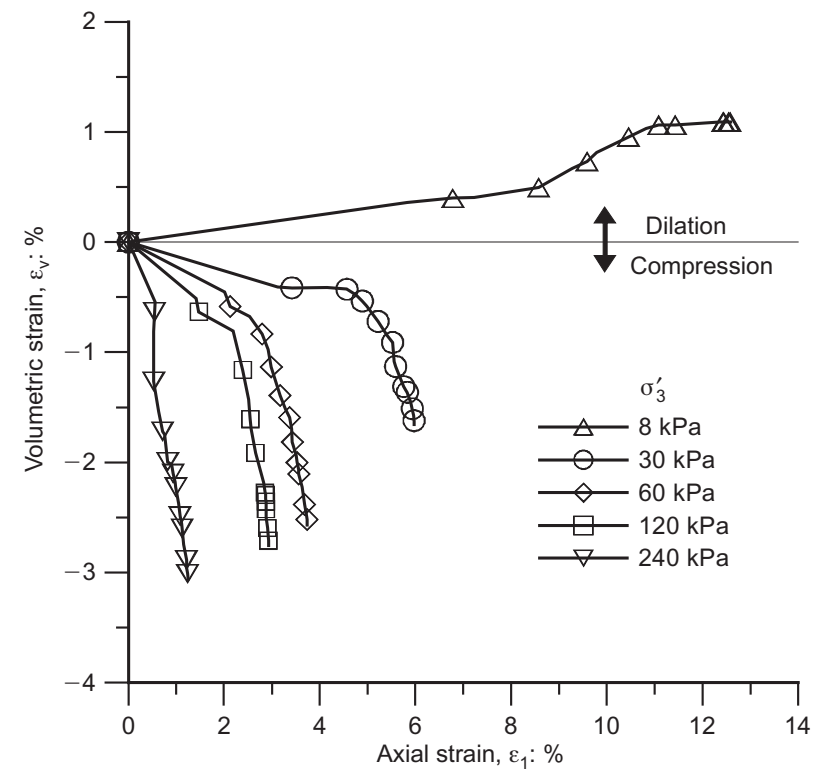

Fig. 8. Relationships between axial and volumetric strains for different confining pressures under cyclic loading (Indraratna et al., 2004)

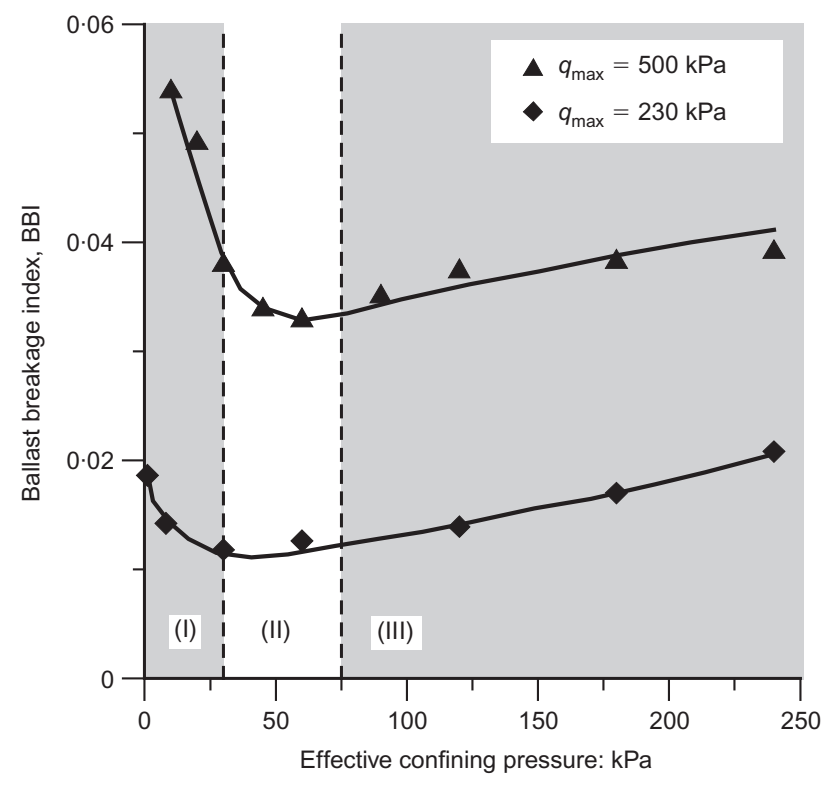

Fig. 9. Effect of confining pressure on particle breakage, showing degradation zones (Indraratna et al., 2005) compressive stable degradation zones. At low confining pressure of the dilatant unstable region $\left(\sigma_{3}^{\prime}<30 \mathrm{kPa}\right)$, ballast specimens are subjected to rapid and considerable axial and expansive radial strains, resulting in an overall volumetric increase or dilation. In this region, particles are given insufficient time to rearrange, and, owing to the excessive axial and radial strains, considerable degradation occurs as a result of shearing and attrition of angular projections. Because of the small confining pressures applied in this region, specimens in this degradation zone are characterised by a limited coordination number and small particle-to-particle contact areas. As the confining pressure is increased to the optimum region $\left(\sigma_{3}^{\prime}=30-\right.$ $75 \mathrm{kPa}$ ), axial strain rate is greatly reduced owing to increased apparent stiffness, and overall volumetric behaviour is slightly compressive. In this region, particles are held together in an optimum array with sufficient lateral confinement to provide an optimum contact stress distribution and increased interparticle contact areas, which results in reducing the risk of breakage associated with stress concentrations. As $\sigma_{3}^{\prime}$ is increased further to the compressive stable region $\left(\sigma_{3}^{\prime}>75 \mathrm{kPa}\right)$, particles are forced against each other, there is limited scope for particle sliding and rolling, and therefore breakage is significantly increased. Particles in this region fail not only at the beginning of loading, when axial strain rates are greatest, but also by the process of fatigue as the number of cycles increases. Because of the large lateral forces being applied to the samples in this region, compressive behaviour is enhanced, which is due partly to the increase in particle breakage.

Although there is no direct measure of in situ confining pressure, it is expected that the effective confining pressures currently being applied to the ballast layer are within the dilatant unstable degradation zone. This small confining pressure is estimated to be less than $20 \mathrm{kPa}$. If ballast breakage is a problem on a particular track, an increase in track confinement pressure may result in decreased degradation and superior track performance. Some measures for increasing confinement include:

(a) reducing sleeper spacing

(b) increasing the height of the shoulder ballast

(c) using intermittent lateral restraints at various parts of the track (Fig. 10)

(d) using winged precast concrete sleepers (Fig. 10).

\section{Ballast settlement}

The settlement of ballast can be both elastic (such as the initial settlement due to the compaction of ballast) and plastic (due to breakage of ballast particles). As identified by Selig and Waters (1994), settlement of ballast may not be a problem if it is occurring uniformly along the length of the track. In fact, differential track settlement is more important than the total track settlement. In the long term, however, the subgrade settlement is more influential. Settlement of ballast is influenced by the magnitude and number of load cycles, as well as by the speed of trains. There is an initial stabilisation stage where settlement is rapid, followed by settlement over an extended period at a decreasing rate. Jeffs and Marich (1987) and Indraratna et al. (1998), based on their experimental studies, reported that the relationship between the number of load applications and settlement of ballast is non-linear. The rail track settlement can be related to the number of load cycles by a semi-logarithmic relationship, as follows. 


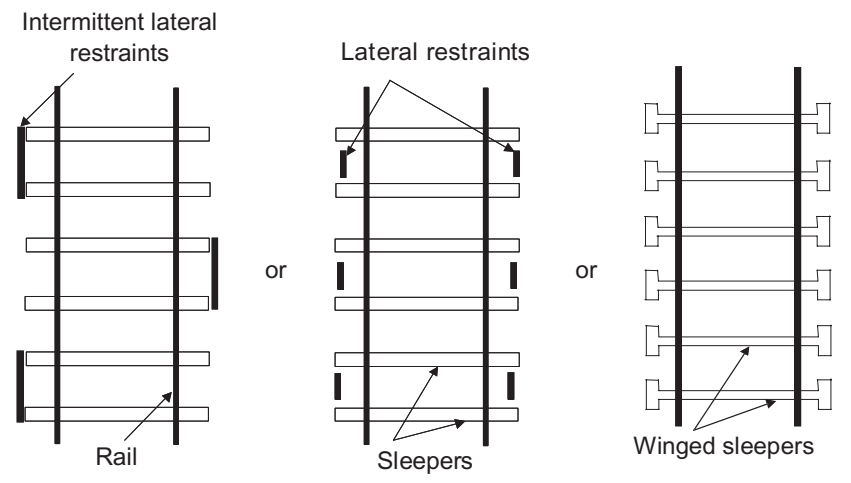

Fig. 10. Increasing confining pressure using intermittent lateral restraints (Indraratna et al., 2004) or winged sleepers

$$
S_{N}=S_{1}(1+k \log N)
$$

where $S_{N}$ is the settlement of ballast at $N$ load cycles, $S_{1}$ is the settlement at the first cycle, and $k$ is an empirical constant depending on the initial compaction, type of ballast, type of reinforcement and degree of saturation. Recent settlement results (Neidhart, 2001) suggest that settlement prediction is approximated by the following equation.

$$
S_{N}=S_{1}+\frac{c \log N}{1+d \log N}
$$

where $c$ and $d$ are shape parameters. This formula implies that the rate of change of ballast settlement is diminutive when the number of cycles is very high (e.g. $N>10^{6}$ ). The rapid initial settlement is followed by gradual deformation with increasing number of load cycles. Hence the settlement of ballast under cyclic load can also be modelled as a power function of the number of load cycles, as follows.

$$
S_{N}=S_{1} N^{b}
$$

where $b$ is an empirical coefficient determined based on nonlinear regression analysis. Indraratna et al. (2000) conducted several tests to investigate the effect of load cycles and axle loads on settlement. They employed equation (6) to model the ballast settlement, as shown in Fig. 11. It is important to note that the variation of the applied load affects only the coefficient $S_{1}$; the coefficient $b$ remains relatively unchanged.

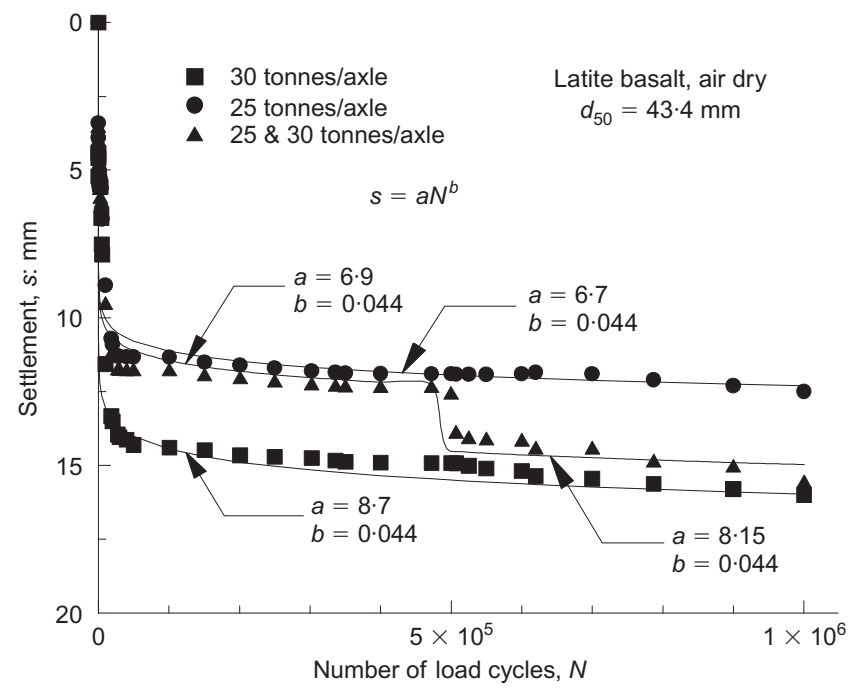

Fig. II. Effect of load cycles and axle loads on settlement (Indraratna et al., 2000)

\section{Improvement of rail track performance using geosynthetics}

Geosynthetics have been used in various ways in new rail tracks and track rehabilitation for almost three decades. When appropriately designed and installed, they provide a cost-effective alternative to more traditional techniques. There are several problems to be addressed in railway tracks: to increase the bearing capacity of the subgrade soil; to prevent contamination of the ballast with subgrade fines; and dissipate the high pore water pressures built up by cyclic train loading. The purpose of the application of geosynthetics within railway construction, similar to other geotechnical engineering projects, can be subdivided into six categories:
(a) separation
(b) reinforcement
(c) filtration
(d) drainage
(e) moisture barrier/waterproofing
( $f$ ) protection.

In ongoing research at the University of Wollongong, and based on the relatively low cost and proven performance of geosynthetics in various railway applications, the authors have conducted an extensive laboratory experimental programme to investigate the effects of different types of geosynthetics in enhancing the mechanical properties of fresh and recycled ballast. In order to reduce the accumulation of discarded ballast, minimise the cost of track maintenance and reduce the environmental degradation of further quarrying of fresh ballast, the selected waste ballast may be cleaned, sieved and reused in the track. However, as the angularity of recycled ballast is decreased by the degradation of sharp corners in previous loading cycles, it is expected that recycled ballast will provide higher settlement and lateral deformation than fresh ballast. Before utilising recycled ballast back on track, its behaviour and performance need to be investigated to ensure that it complies with the required stability and safety criteria stipulated by the various rail authorities. In addition, a plane-strain finite element analysis that utilises the code PLAXIS was used to simulate the behaviour of ballast with and without geosynthetics in the prismoidal triaxial rig. The finite element numerical model was then used to obtain the optimum location of geosynthetics in rail track substructure. The laboratory experiments and the finite element analysis are described in this section, and their findings are explained.

\section{Material properties}

Fresh ballast was collected from Bombo quarry near Wollongong city, Australia. It represents sharp angular aggregates of crushed volcanic basalt (latite). Recycled ballast was collected from Chullora stockpile, Sydney. The recycled ballast consisted of semi-angular crushed rock fragments. A capping layer (sub-ballast) was used beneath the ballast specimen to act as a filter and separator between the subgrade and ballast bed. The capping layer consisted of $100 \mathrm{~mm}$ of compacted mixture of fine gravel and sand $\left(d_{50}=\right.$ $0 \cdot 26 \mathrm{~mm}$ and $C_{\mathrm{u}}=5$ ). In order to resemble the real situation of railway track, a thick subgrade layer is required. However, due to limitations in laboratory testing and conducting a comparative study only on degradation and settlement of ballast under cyclic loading, a thin layer $(50 \mathrm{~mm})$ of 
compacted clay was used beneath the capping layer. All fresh and recycled ballast specimens were prepared following a single gradation curve $\left(d_{50}=35 \mathrm{~mm}\right.$ and $\left.C_{\mathrm{u}}=1 \cdot 6\right)$.

Three types of geosynthetics (geogrid, woven geotextile and geocomposite) were used in the current study in order to stabilise the fresh and recycled ballast. All of these geosynthetics are made of polypropylene. The geogrid used was a bi-oriented geogrid with rectangular apertures of $27 \mathrm{~mm} \times 40 \mathrm{~mm}$ with $420 \mathrm{~g} / \mathrm{m}^{2}$ unit mass. The peak tensile strength of the geogrid is $30 \mathrm{kN} / \mathrm{m}$. The geotextile was a high-strength woven polymer with $0.25 \mathrm{~mm}$ pore size and $450 \mathrm{~g} / \mathrm{m}^{2}$ unit mass. The tensile strength of the geotextile is $80 \mathrm{kN} / \mathrm{m}$. The geocomposite, with $560 \mathrm{~g} / \mathrm{m}^{2}$ unit mass, was composed of the same geogrid bonded with a non-woven polypropylene geotextile. The purpose of adding the nonwoven geotextile to the geogrid is to provide filtration and separation functions that are absent in the geogrid alone owing to its large apertures.

\section{Laboratory model experiments}

A large-scale prismoidal triaxial rig $800 \mathrm{~mm}$ long, $600 \mathrm{~mm}$ wide and $600 \mathrm{~mm}$ high was built at the University of Wollongong to model the cyclic loading response of ballasted tracks. Fig. 12 shows the large-scale prismoidal triaxial rig used, and a schematic view of the rig is shown in Fig. 13. By allowing the lateral strain of ballast upon loading, this triaxial rig with unrestrained sides provides a reliable

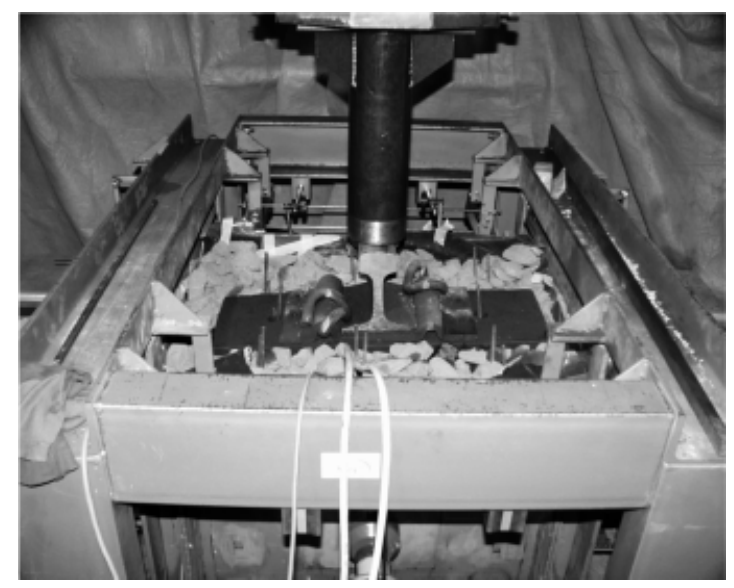

Fig. 12. Large-scale prismoidal triaxial equipment designed at University of Wollongong

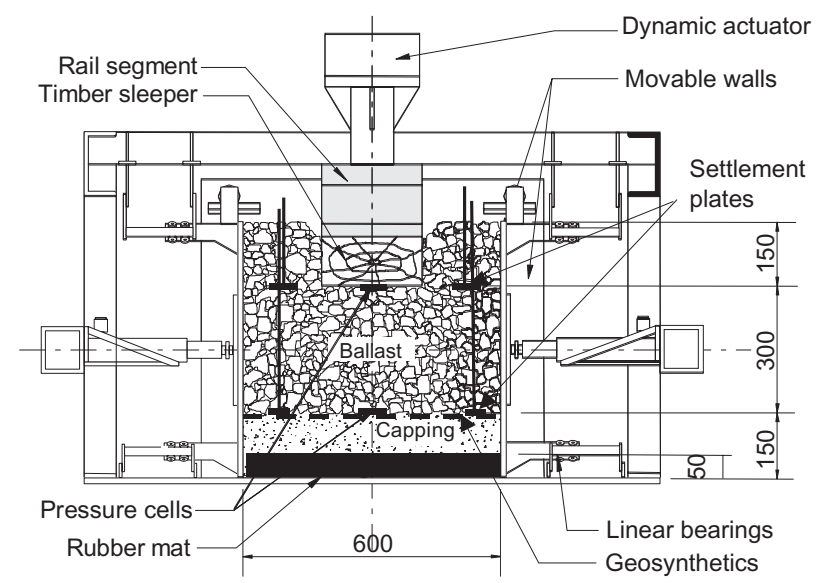

Fig. 13. Schematic view of large-scale prismoidal triaxial apparatus built at University of Wollongong (Indraratna and Salim, 2003) facility for physical modelling of ballast under cyclic loading. In the laboratory model, a servo-hydraulic actuator provides the vertical cyclic load, and the load is transmitted to the ballast through a $100 \mathrm{~mm}$ steel ram and a rail-sleeper arrangement. A system of hydraulic jacks and load cells attached to the vertical walls of the rig provides the intermediate and minor principal stresses. More details of this apparatus can be found in Indraratna et al. (2002). In order to model a real track, the prismoidal triaxial chamber was filled with ballast and other materials in several layers: the bottom layer (50 $\mathrm{mm}$ compacted clay), the capping layer $(100 \mathrm{~mm})$, load-bearing ballast $(300 \mathrm{~mm})$, and the top layer (150 mm crib ballast). A timber sleeper (650 $\mathrm{mm}$ long and $220 \mathrm{~mm}$ wide) and a rail segment were placed above the compacted load-bearing ballast. The space between the sleeper and the walls was filled with crib ballast. A geosynthetic reinforcement layer was placed at the ballast/ capping interface. Two pressure cells were installed, at the sleeper/ballast and ballast/capping interfaces, to monitor the vertical stresses on the ballast specimen. Eight settlement plates were installed at each of the sleeper/ballast and ballast/capping interfaces. The ballast and capping layers were compacted with a vibratory hammer in several layers, each about $75 \mathrm{~mm}$ thick, to achieve representative field densities. The bulk unit weights of the compacted ballast layer and capping layer were about $15.3 \mathrm{kN} / \mathrm{m}^{3}$ and $21 \cdot 3 \mathrm{kN} / \mathrm{m}^{3}$ respectively. The initial void ratio of the ballast layer was about $0 \cdot 74$. All test specimens were compacted to the same initial density. The deformations of the ballast and the lateral movements of the vertical walls were measured using 18 LVDTs, which were connected to a data acquisition system. After preparing the test specimen, small lateral stresses $\left(\sigma_{2}^{\prime}=10 \mathrm{kPa}\right.$ and $\left.\sigma_{3}^{\prime}=7 \mathrm{kPa}\right)$ were applied to the vertical walls of the triaxial chamber through hydraulic jacks, to simulate shoulder ballast and field confining stresses. The cyclic load was applied with a maximum load intensity of $73 \mathrm{kN}$ to produce the same average contact stress at the sleeper/ballast interface for a typical $25 \mathrm{t} /$ axle traffic load. The tests were conducted at a frequency of $15 \mathrm{~Hz}$, simulating a speed of $80 \mathrm{~km} / \mathrm{h}$. The total number of load cycles applied in each test was half a million.

\section{Results and discussion of laboratory tests}

The variation of total settlement of fresh and recycled ballast specimens against number of load cycles is shown in Fig. 14 for samples with and without geosynthetic stabilisation. This figure confirms that the behaviour of railway ballast under cyclic loading is highly non-linear. Similar behaviour was also reported in the previous studies (Indraratna et al., 1998, 2000). As expected, fresh ballast produces the minimum settlement, and recycled ballast without reinforcement shows much higher settlement than fresh ballast. Fig. 14 clearly shows that the inclusion of geocomposite in both fresh and recycled ballast improves its resistance to settlement, and that the recycled ballast (with geosynthetics) compares well with fresh ballast (without geosynthetics). Inclusion of either geotextile or geogrid in recycled ballast improves the settlement behaviour moderately, but not to the same extent as that of the geocomposite.

The sleeper settlement data and measurements of settlement plates placed at the ballast/capping interface were used to calculate the vertical strain $\left(\varepsilon_{1}\right)$ of the ballast specimens. The lateral strains of ballast, $\varepsilon_{\mathrm{L}}$ (the strain parallel to the sleeper), were calculated from the average lateral movements of the vertical walls and the initial lateral dimensions of the specimen. Fig. 15 shows the vertical strain 


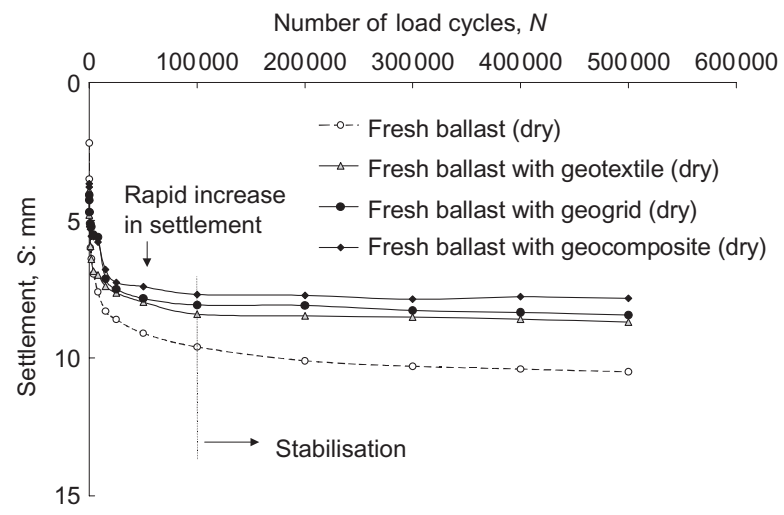

(a)

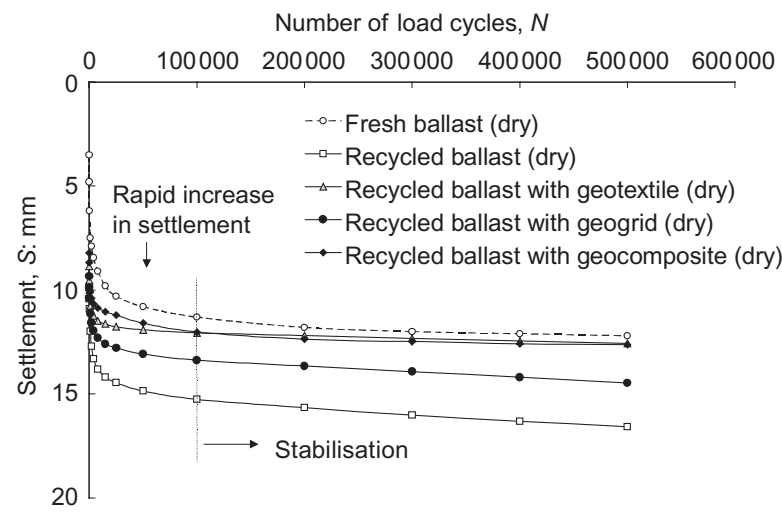

(b)

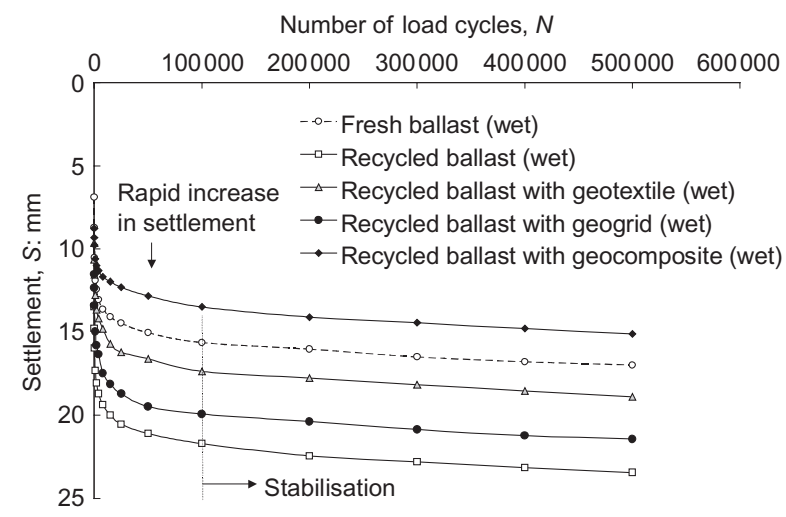

(c)

Fig. 14. Settlement of ballast with and without geosynthetics (Indraratna et al., 2002): (a) fresh ballast (dry specimens); (b) recycled ballast (dry specimens); (c) recycled ballast (saturated specimens)

of ballast against the number of load cycles for saturated and dry test specimens. This figure verifies that the geogrid-geotextile composite is more effective, in reducing $\varepsilon_{1}$, than the geogrid or geotextile used alone. Fig. 15 also indicates that, after the initial rapid deformation, the vertical strain of ballast is related linearly with the number of load cycles, irrespective of the type of ballast and reinforcement.

The variations of strain parallel to the sleeper, $\varepsilon_{\mathrm{L}}$ (in the direction of the lowest confinement), with increasing number of load cycles are shown in Fig. 16. The lateral strain of recycled ballast with no stabilisation is higher than that of fresh ballast. The inclusion of geogrids in recycled ballast decreases the lateral strain slightly. However, the inclusion of geotextiles or geocomposites decreases $\varepsilon_{\mathrm{L}}$ to even less than that of fresh ballast at a higher number of load cycles.

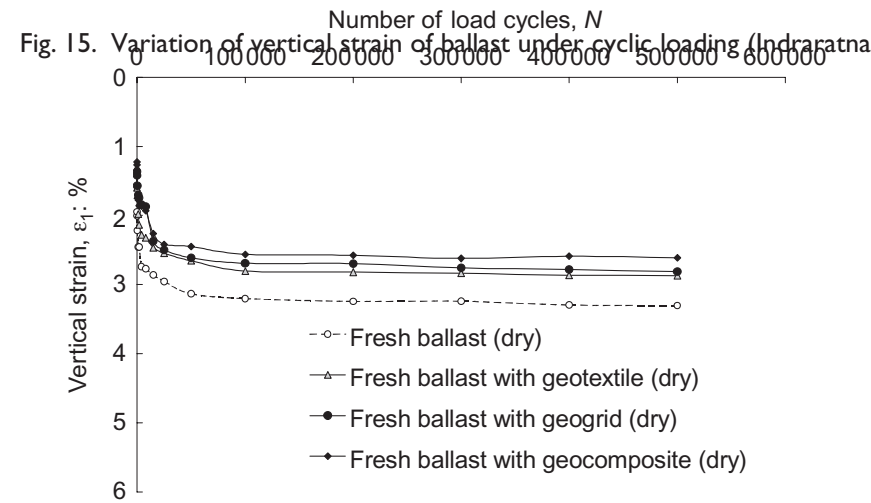

(a)

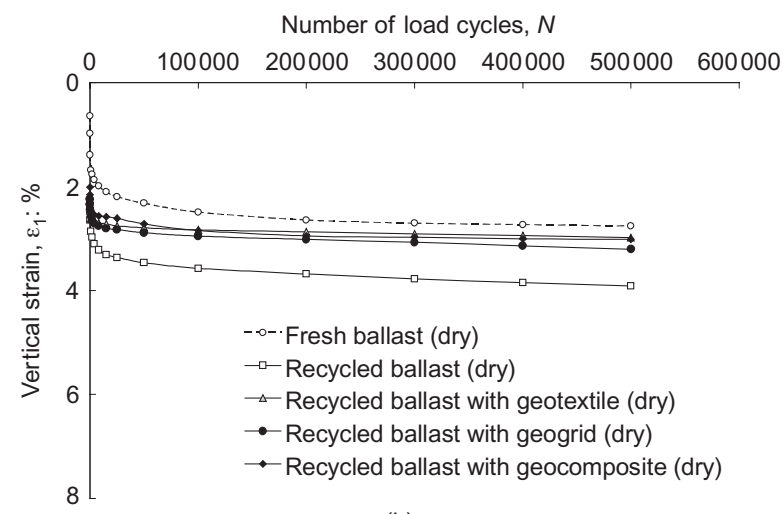

(b)

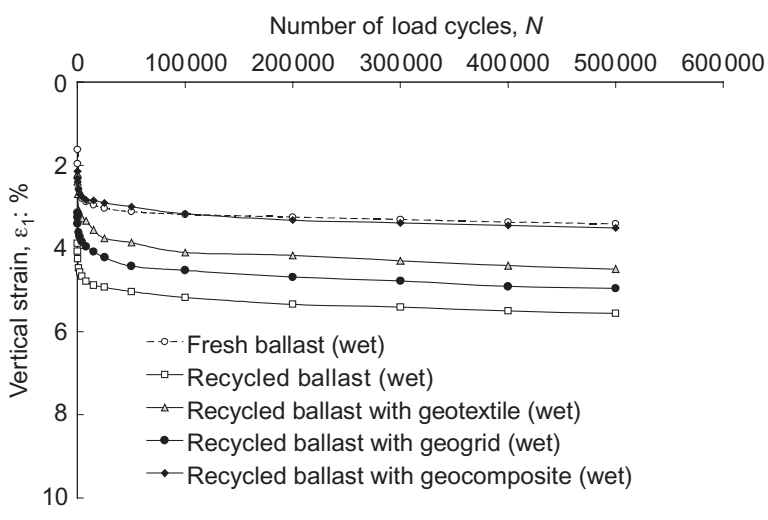

(c)

As can be seen in Figs 14-16, the deformation results for ballast specimens tested in dry conditions were similar to those for saturated samples but indicating less settlement, vertical strains and lateral strains.

\section{Particle breakage}

In order to evaluate the breakage characteristics of ballast based on Marsal's method (Marsal, 1967), each ballast specimen was sieved before and after the test, and the changes in percentage retained on each sieve size, $\Delta W_{k}$, were recorded and breakage index $B_{\mathrm{g}}$, which is defined as the sum of the positive values of $\Delta W_{k}$ with different grain sizes of ballast, was calculated. The variation of $\Delta W_{\mathrm{k}}$ with different grain sizes of ballast is shown in Fig. 17, and the breakage index 
Number of load cycles, $N$

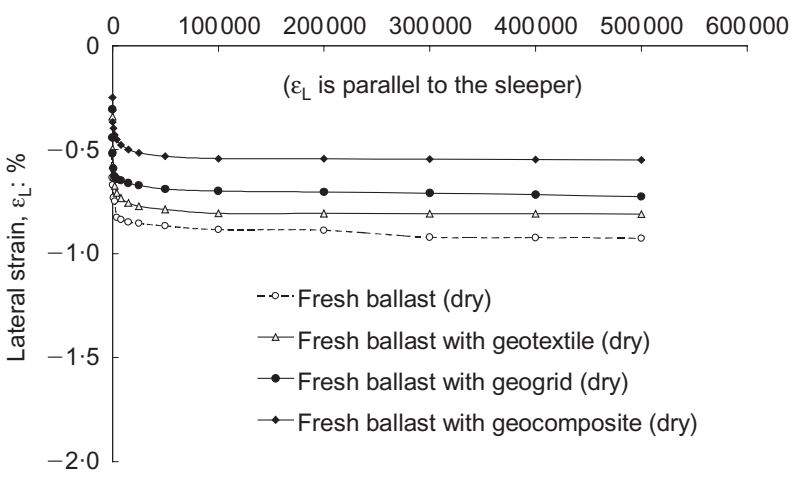

(a)

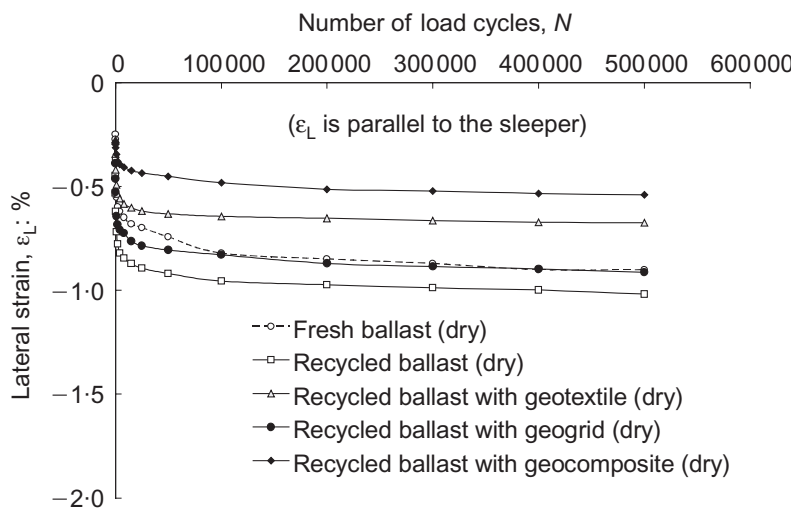

(b)

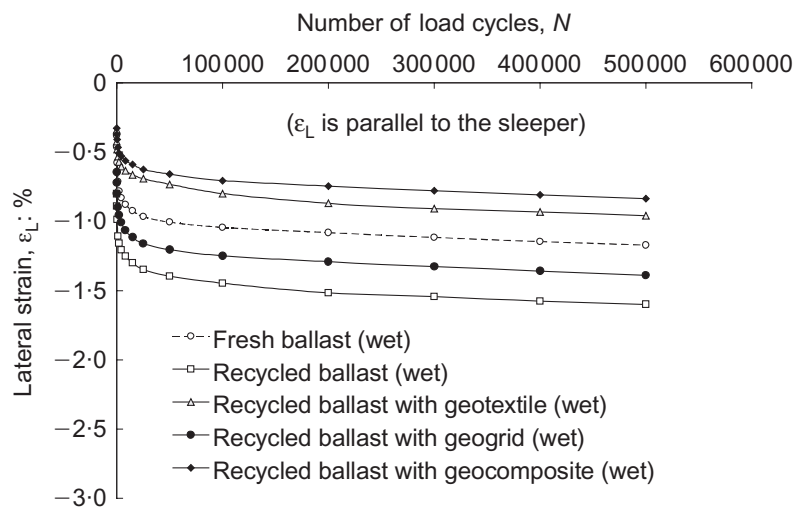

(c)

Fig. 16. Variation of lateral strain of ballast under cyclic loading (Indraratna et al., 2002): (a) fresh ballast (dry specimens); (b) recycled ballast (dry specimens); (c) recycled ballast (saturated specimens)

values of different ballast specimens used in this study are given in Table 1. It is clear that fresh ballast shows the least degradation, whereas recycled ballast is more vulnerable to breakage. It can be noted that the inclusion of geosynthetics with recycled ballast increases its resistance to degradation. However, the inclusion of geosynthetics with fresh ballast has an insignificant effect on reduction of ballast degradation.

The test results indicate that recycled ballast experiences $97 \%$ more breakage than fresh ballast under similar loading conditions. The presence of microcracks in recycled ballast from previous loading cycles is believed to be a major reason for its higher particle degradation. The inclusion of a geogrid-geotextile composite layer in recycled ballast decreases particle breakage by about $48 \%$ (in dry conditions)

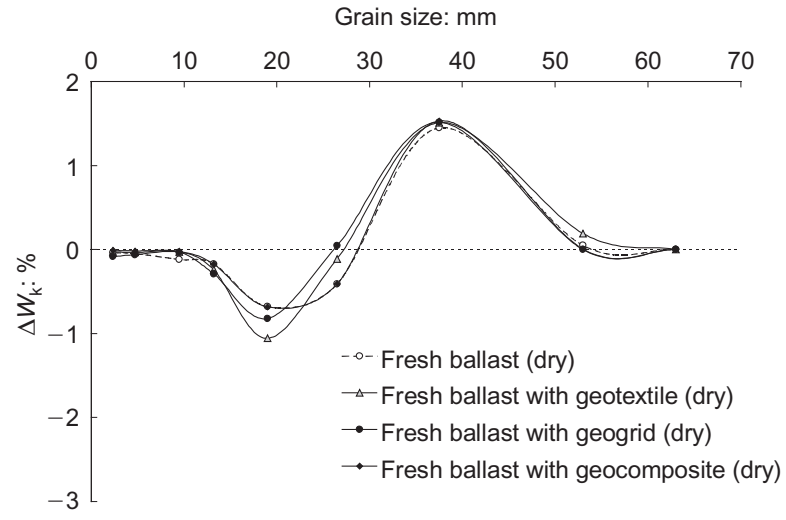

(a)

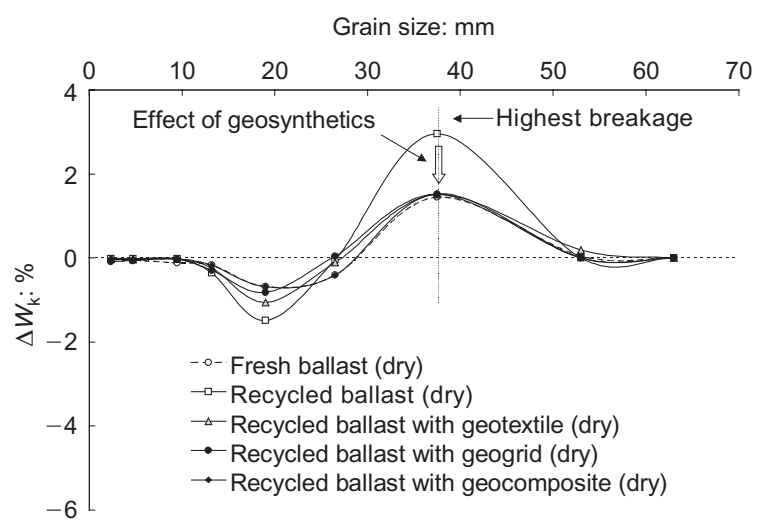

(b)

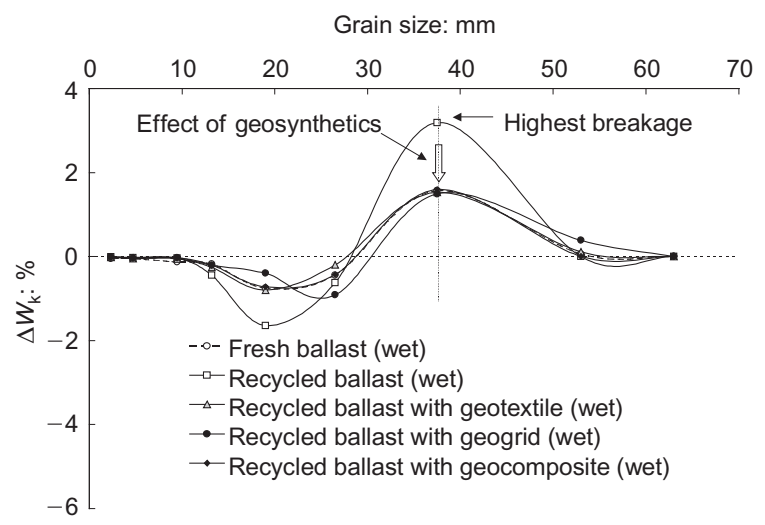

(c)

Fig. 17. Change in particle size of ballast under cyclic loading (Indraratna et al., 2002): (a) fresh ballast (dry specimens); (b) recycled ballast (dry specimens); (c) recycled ballast (saturated specimens)

and $50 \%$ (in wet conditions). According to the experimental results, there is no doubt that recycled ballast stabilised with geocomposites $\left(B_{\mathrm{g}}=1 \cdot 60\right)$ is as good as fresh ballast $\left(B_{\mathrm{g}}=\right.$ $1 \cdot 63$ ) in terms of breakage assessment.

\section{Numerical modelling}

In this part, the feasibility of using finite element analysis (FEA) to simulate the behaviour of ballast (wet fresh without geogrids, and wet recycled with/without geogrids) in the prismoidal triaxial rig was investigated and used to obtain the optimum location of geosynthetics in rail track substructure. The results of the experimental work carried out on wet fresh and wet recycled ballast shown in Fig. 14(c) were used to calibrate the finite element model. The large-scale 


\begin{tabular}{l|c|c}
\hline \multirow{2}{*}{ Type of test } & \multicolumn{2}{|c}{ Breakage index, $B_{g}=\Sigma(\Delta W k>0)$} \\
\cline { 2 - 3 } & Sample in dry condition & Sample in wet condition \\
\hline Fresh ballast & 1.50 & 1.63 \\
Recycled ballast & 2.96 & 3.19 \\
Recycled ballast with geotextile & 1.56 & 1.64 \\
Recycled ballast with geogrid & 1.70 & 1.88 \\
Recycled ballast with geocomposite & 1.52 & 1.60 \\
Fresh ballast with geotextile & 1.54 & - \\
Fresh ballast with geogrid & 1.49 & - \\
Fresh ballast with geocomposite & 1.42 & - \\
\hline
\end{tabular}

prismoidal triaxial rig shown in Fig. 13 was numerically simulated using the finite element code PLAXIS (2004). The finite element mesh used to simulate the track section in Fig. 13 was discretised using 15 node plane-strain triangular elements (Fig. 18). Because of symmetry, only one half of the track section was considered in the numerical model. The material parameters and constitutive models used for each component of the track section are given in Table 2. Full details of the constitutive models used in Table 2 and their parameters can be found in the PLAXIS manual (PLAXIS, 2004). The train load was simulated by applying an equivalent uniformly distributed vertical dynamic load on the sleeper. This dynamic load has the same average contact stress at the sleeper/ballast interface as a typical $25 \mathrm{t}$ /axle traffic load with a frequency of $15 \mathrm{~Hz}$ with a simulated speed of $80 \mathrm{~km} / \mathrm{h}$, as mentioned previously. A total number of 100 load cycles were applied in the finite element analysis, and their results were compared with the experimental data at the same number of load cycles. Lateral distributed static load was also applied to the movable steel walls of the prismoidal rig to simulate a field confining pressure of $10 \mathrm{kPa}$. The damping effect was neglected in this study. The results of the finite element analysis are given in Table 3. It

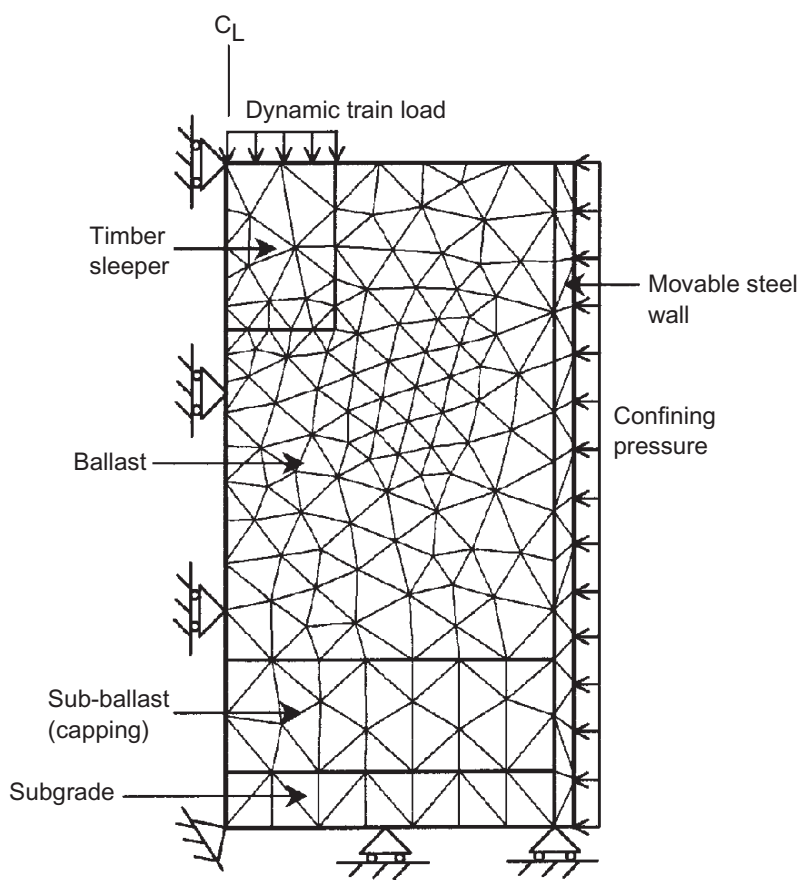

Fig. 18. Finite element mesh used in PLAXIS for prismoidal triaxial apparatus can be seen that good agreement is achieved between the finite element numerical model and the test results. This reveals that numerical modelling using finite element analysis has the feasibility to simulate well the behaviour of ballast under cyclic loading. Table 3 also demonstrates that finite element analysis can simulate well the effect of geosynthetics on the behaviour of recycled ballast.

Geosynthetics for improving the deformation characteristics of ballast could be included anywhere beneath the sleeper and within the ballast layer. However, to allow for tamping, geosynthetics must not be placed at a depth less than $150 \mathrm{~mm}$ below the sleeper. In this study, an attempt was carried out using finite element analysis to obtain the optimum location of geosynthetics for improving the deformation characteristics of recycled ballast. The placement depth of geosynthetics beneath the sleeper was started at $300 \mathrm{~mm}$ (i.e. at the ballast/capping interface) and then decreased by steps of $50 \mathrm{~mm}$ so that the placement depth of geosynthetics could be tested at 250, 200, 150 and $100 \mathrm{~mm}$ respectively. The results are given in Fig. 19, which demonstrates that the deformation of the recycled ballast was decreased from $13.3 \mathrm{~mm}$ to $12.1 \mathrm{~mm}$ when the placement depth of geosynthetics beneath the sleeper was reduced from $300 \mathrm{~mm}$ to $200 \mathrm{~mm}$. Fig. 19 also shows that there was almost no improvement in the deformation characteristics of the recycled ballast when the placement depth of geosynthetics was decreased from $200 \mathrm{~mm}$ to $150 \mathrm{~mm}$, below which the deformation of the recycled ballast increased again to $16.3 \mathrm{~mm}$ at $100 \mathrm{~mm}$ placement depth. This demonstrates that there is a threshold depth below which geosynthetics cannot be kept in place under the effect of train wheel load, and thus geosynthetics do not provide the confinement required for ballast to resist settlement. This threshold depth is shown in Fig. 19 to be between 150 and $200 \mathrm{~mm}$. This indicates that the optimum location of geosynthetics for improving the deformation characteristics of recycled ballast may be taken to be $200 \mathrm{~mm}$. It should be noted that, to allow for ballast cleaning in the field, if the required thickness of ballast is more than $200 \mathrm{~mm}$, placement of geosynthetics at the optimum location (i.e. at $200 \mathrm{~mm}$ ) may not be practically possible. Consequently, in such cases, the location of geosynthetics may be needed to be at the ballast bed (i.e. at the ballast/capping interface).

\section{Improvement of soft formations using geosynthetic vertical drains}

Because of the rapid growth of infrastructure in the world, particularly in the coastal regions of many countries, it is 
Table 2. Parameters of the rail track materials used in the finite element analysis

\begin{tabular}{|c|c|c|c|c|c|c|c|}
\hline \multirow[b]{2}{*}{ Parameter } & \multicolumn{2}{|c|}{ Ballast } & \multirow[b]{2}{*}{ Sub-ballast } & \multirow[b]{2}{*}{ Subgrade } & \multirow[b]{2}{*}{ Timber sleeper } & \multirow[b]{2}{*}{ Steel walls } & \multirow[b]{2}{*}{ Geogrids } \\
\hline & Fresh & Recycled & & & & & \\
\hline Model & $\mathrm{HS}$ & $\mathrm{HS}$ & $M C$ & Elastic & Elastic & Elastic & Elastic \\
\hline$\gamma: \mathrm{kN} / \mathrm{m}^{3}$ & $15 \cdot 3$ & $15 \cdot 3$ & $21 \cdot 3$ & 17 & - & - & - \\
\hline$E_{50}^{\text {ref }}: M P a$ & 150 & 70 & - & - & - & - & - \\
\hline$E_{\text {oed }}^{\text {ref }}: M P a$ & 150 & 70 & - & - & - & - & - \\
\hline$E_{\mathrm{ur}}^{\mathrm{ref}}: \mathrm{MPa}$ & 450 & 210 & - & - & - & - & - \\
\hline $\mathrm{E}: \mathrm{MPa}$ & - & - & 100 & 40 & $10 \cdot 55$ & 210000 & - \\
\hline$E A: \mathrm{kN} / \mathrm{m}$ & - & - & - & - & - & - & 525 \\
\hline$v$ & - & - & 0.35 & 0.4 & 0.33 & 0.33 & - \\
\hline$\nu_{\mathrm{ur}}$ & 0.2 & 0.2 & - & - & - & - & - \\
\hline$c: k N / m^{2}$ & 0.0 & 0.0 & 0.0 & - & - & - & - \\
\hline$\phi:$ degrees & 50 & 45 & 45 & - & - & - & - \\
\hline$\Psi:$ degrees & 0 & 0 & 0 & - & - & - & - \\
\hline$P_{\text {ref }}: \mathrm{kN} / \mathrm{m}^{2}$ & 100 & 100 & - & - & - & - & - \\
\hline $\mathrm{m}$ & 0.5 & 0.5 & - & - & - & - & - \\
\hline$K_{0}^{\mathrm{nc}}$ & 0.3 & 0.3 & - & - & - & - & - \\
\hline$R_{f}$ & 0.9 & 0.9 & - & - & - & - & - \\
\hline
\end{tabular}

HS, hardening-soil model; MC, Mohr-Coulomb model; $\gamma$, unit weight; $E_{50}^{\text {ref }}$, secant stiffness at $50 \%$ strength for loading conditions; $E_{u r}^{\text {ref }}$, triaxial unloading/ reloading stiffness; $E_{\text {oed }}^{\text {ref }}$, tangent stiffness for primary oedometer loading; $E A$, elastic normal (axial) stiffness; $v$, Poisson's ratio for loading conditions; $v_{\text {ur }}$, Poisson's ratio for unloading/reloading conditions; $c$, effective cohesion; $\phi$, effective friction angle; $\Psi$, dilatancy angle; $P_{\text {ref }}$, reference confining pressure; $m$, stress-dependent stiffness factor; $K_{0}^{\text {nc }}$, coefficient of earth pressure at rest for normal consolidation; $R_{\mathrm{f}}$, failure ratio.

Table 3. Deformation of ballast at 100 load cycles by test and finite element analysis

\begin{tabular}{l|c|c|c|c|c|c}
\hline \multirow{2}{*}{ Parameter } & \multicolumn{2}{|c|}{ Wet fresh ballast } & \multicolumn{2}{c|}{ Wet recycled ballast } & \multicolumn{2}{c}{$\begin{array}{c}\text { Wet recycled ballast stabilised with geogrids at ballast/ } \\
\text { capping interface }\end{array}$} \\
\cline { 2 - 7 } & Test & FEA & Test & FEA & Test & FEA \\
\hline Settlement: $\mathrm{mm}$ & 10.5 & 11.2 & 15.9 & 15.8 & 13.4 & 13.3 \\
Vertical strain: \% & 2.3 & 2.9 & 4.3 & 4.5 & 3.4 & 3.8 \\
\hline
\end{tabular}

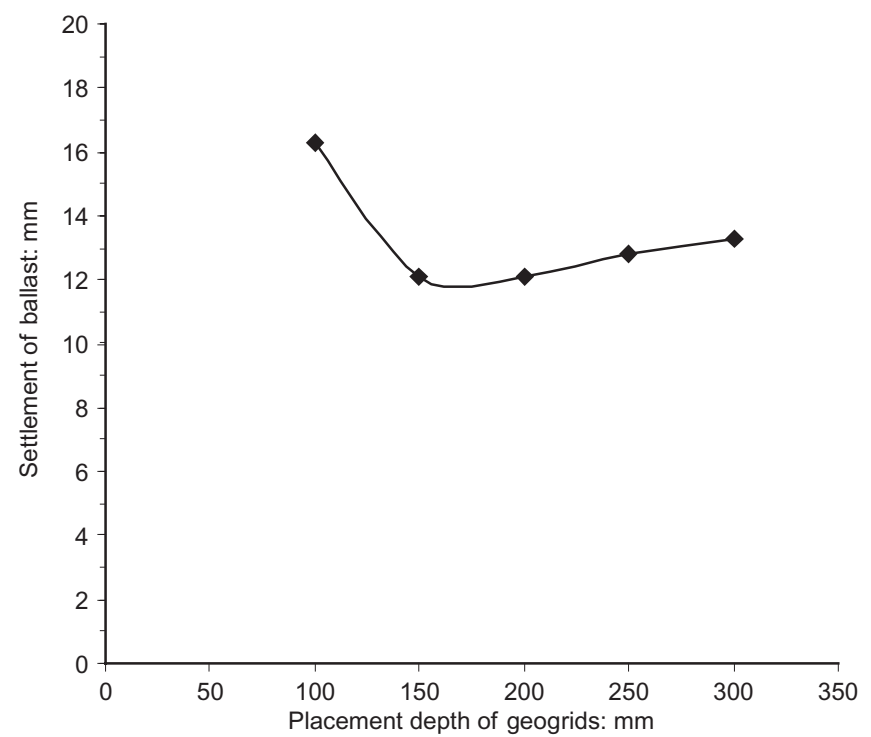

Fig. 19. Optimum location of geosynthetics in rail track substructure by finite elements

highly likely that engineers will be faced with the construction of embankments and railways on soft clay formations with high compressibility and low bearing capacity. In order to stabilise soft formations, different technical aspects of ground improvement (such as replacement, dewatering, densification, solidification and reinforcement) should be considered. The application of preloading over unconsolidated soft soil is regarded as one of the classical and popular methods in practice. However, in the case of thick soil deposits with low permeability, the consolidation time is considerably long: hence a system of vertical drains is often introduced to achieve accelerated radial drainage and consolidation. In order to demonstrate the impact of the application of vertical drains on the rail track, an illustrative example of a rail track section was numerically modelled using finite element analysis (PLAXIS). The track section was discretised using 15 node plane-strain triangular elements, and, because of symmetry, only one half of the track was considered (Fig. 20). All track materials (rail, sleeper, ballast, sub-ballast and subgrade) were modelled as elastic materials and were given the same elastic parameters of the materials used in Table 2. The train load was simulated as a static line load of $125 \mathrm{kN} / \mathrm{m}$ that simulated typical $25 \mathrm{t} /$ axle traffic. The simulation results for the illustrative example for point $\mathrm{A}$ at the middle of the soft subgrade layer are given in Fig. 21. It can be seen that the application of vertical drains significantly reduces the time needed for the dissipation of excess pore water pressure that was built up by train load at point $\mathrm{A}$, and, as a result, the consolidation time will be considerably reduced.

The performance of various types of vertical drain, 


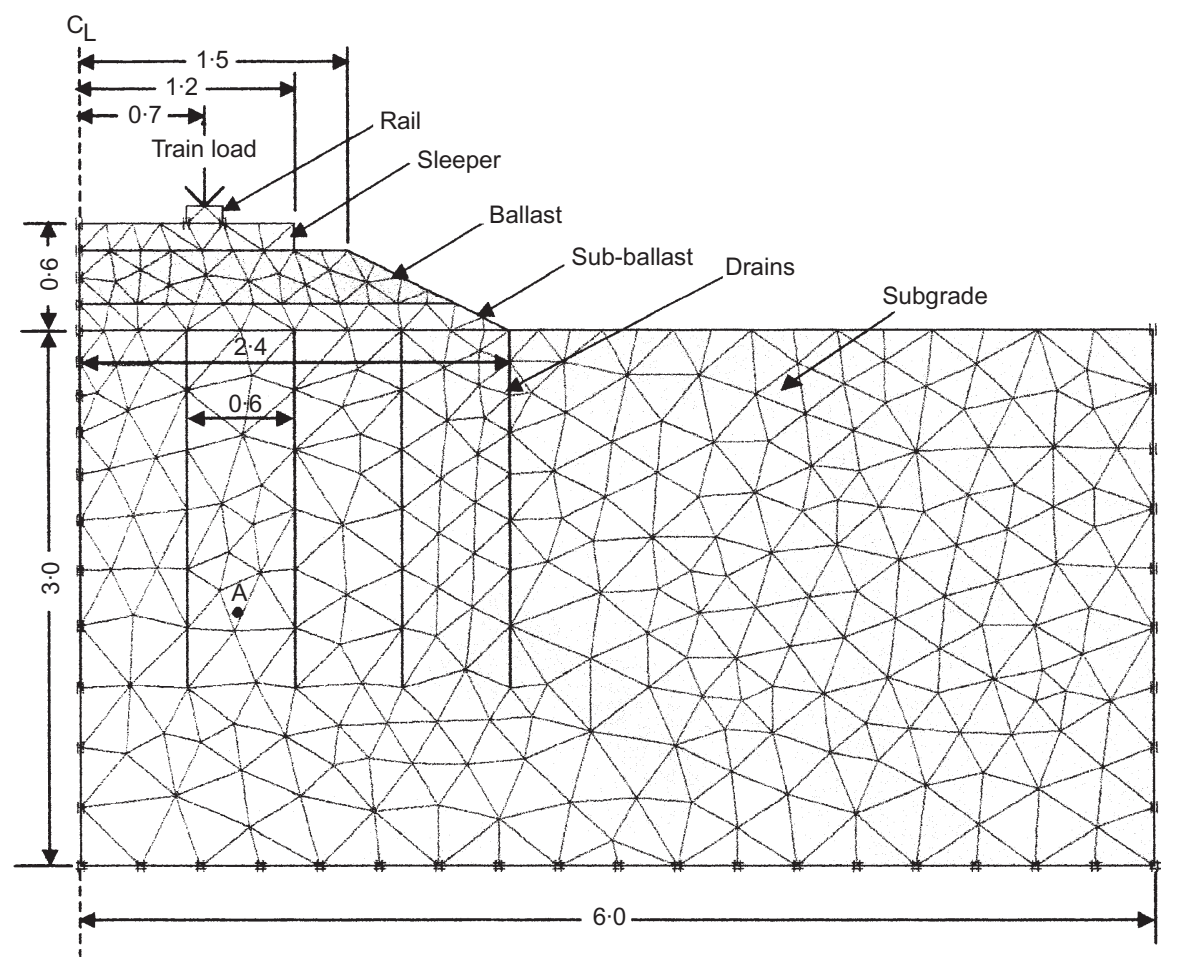

Fig. 20. Finite element configuration of illustrative example of rail track model

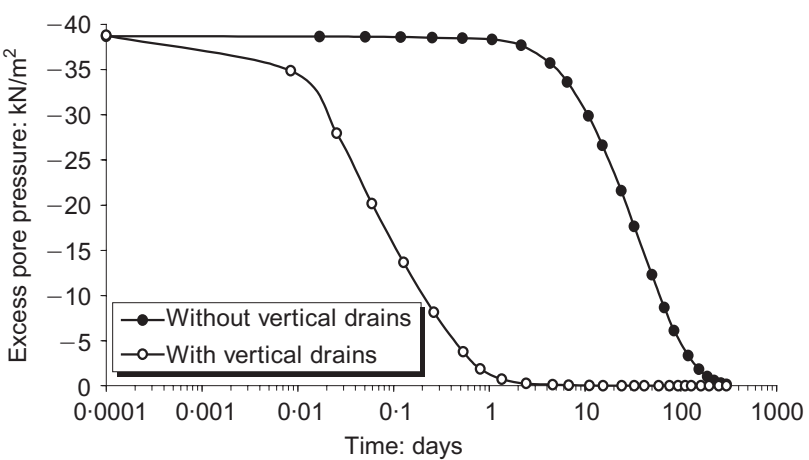

Fig. 2I. Effect of vertical drains on excess pore water pressure at point $A$ for illustrative example of rail track model

including gravel piles, sand compaction piles, sand drains and prefabricated (geosynthetic) vertical drains, have been investigated by several researchers (Bergado et al., 1991; Indraratna and Redana, 1999; Holtz et al., 2001). It was found that, among the various techniques, prefabricated vertical drains (PVDs) provide a very cost-effective method (Indraratna and Bamunawita, 2002). Although PVDs are much smaller in cross-section than sand drains, the installation patterns are similar to those for sand drains (square or triangular), with typical spacing ranging between 1.2 and $4.0 \mathrm{~m}$. The installation costs of PVDs are much lower than those of sand drains. As reported by Holtz et al. (2001), sand drains cost five to eight times more than PVDs. Furthermore, the maximum length of PVDs can be up to $60 \mathrm{~m}$, which is twice the maximum length of conventional sand drains. Current PVDs have a rectangular cross-section, typically $100 \mathrm{~mm} \times 5 \mathrm{~mm}$, and are manufactured in long thin strips or bands. They are geocomposites, and consist of a plastic core with grooves, studs or channels that are surrounded by a filter, most commonly made of a non-woven geotextile. The installation of PVDs is conducted by pushing a steel mandrel into the clay layer down to the desired depth. It is important to note that the insertion of the mandrel causes significant disturbance of the clay layer surrounding the drain, resulting in a smear zone. Consequently, significant excess pore pressures build up and the horizontal permeability of the clays decreases. In order to study the consolidation behaviour of soft soils stabilised with PVDs, and investigate the factors affecting the performance of vertical drains, an extensive research programme has been conducted at the University of Wollongong, and a description of the experiments conducted and the results obtained is given below.

\section{Laboratory testing}

A large-scale radial drainage consolidometer was designed and installed at UoW to investigate the role of PVDs for soil formation stabilisation. This apparatus, as shown in Fig. 22, consists of two half-sections made of stainless steel. The internal diameter and the height of the cell are $450 \mathrm{~mm}$ and $950 \mathrm{~mm}$ respectively. The loading system, with a maximum capacity of $1200 \mathrm{kN}$, is applied by an air jack compressor system via a piston. The settlement is measured by a displacement transducer placed at the top of this piston, and several pore pressure transducers have been installed to measure the excess pore water pressures at various points. This specially designed large-scale consolidometer has been used to study the different factors influencing the performance of PVDs. The main factors studied are:

(a) estimation of smear zone

(b) well resistance of long PVDs

(c) vacuum pressure

(d) drain unsaturation as a result of the installation process

(e) soil properties

$(f)$ influence zone of drains

(g) drainage boundary conditions. 


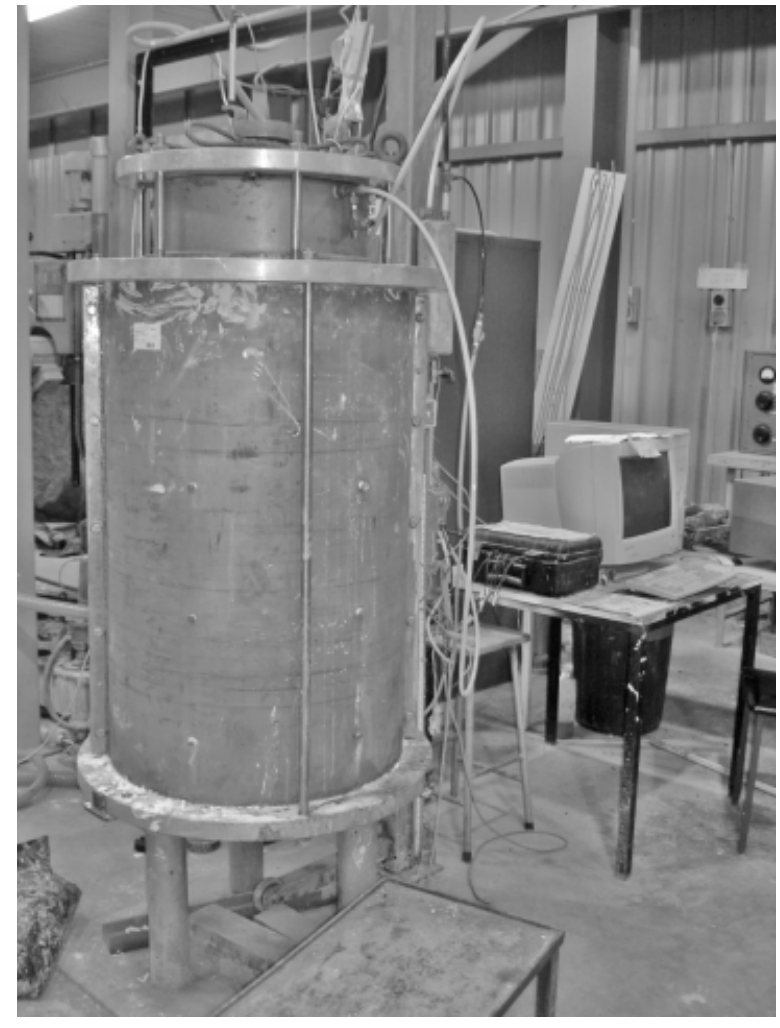

Fig. 22. Large-scale consolidometer built at University of Wollongong

\section{Analysis of results}

Presentation of the analytical, theoretical, numerical and experimental findings of the research on vertical drains at UoW is beyond the scope of this paper. In addition, the effects of dynamic loading (by trains) on soft clay formation stabilised with PVDs is currently ongoing. Thus only some remarks that were drawn from various research phases at UoW regarding the use of PVDs in high-plasticity clays, are given below.

(a) The prefabricated vertical drains (PVDs) not only increase the settlement rate, but also reduce the lateral deformation, and hence decrease the risk of damage to adjacent structures.

(b) The observed retarded efficiency of drains can be related to the smear effect, which is due to soil disturbance as a result of drain installation by mandrel. As the installation of PVDs is relatively fast, significant pore water pressures build up in the smear zone. The radial extent of the smear zone is about 3-4 times the equivalent radius of the vertical drain (Indraratna and Redana, 2000).

(c) Dissipation of pore pressure induced by PVD installation is time-dependent, and occurs without significant soil settlement. However, it causes a reduction in void ratio, and therefore the horizontal permeability of the soil in the smear zone will be reduced.

(d) Unsaturation of the soil adjacent to the drain can occur as a result of mandrel withdrawal. The occurrence of soil unsaturation at the PVD boundary retards the pore pressure dissipation. Implementing this unsaturated soil layer adjacent to the PVD improves the accuracy of numerical model predictions.

(e) The application of vacuum pressure increases the rate of consolidation owing to increased pore pressure gradient towards the drain. However, applied vacuum pressure at the drain top may not always be propagated to the bottom part of the drain, particularly for the majority of long PVDs installed in soft clay.

$(f)$ The inclusion of the smear effect and well resistance improves the accuracy of settlement, lateral displacement and pore pressure predictions.

(g) According to Indraratna and Redana (2000), the well resistance of long PVDs is a crucial factor in simulation of the consolidation process. However, well resistance is not significant when drain length is shorter than about $15 \mathrm{~m}$.

\section{The need for geosynthetically improved tracks and compacted formation soil for tsunami- devastated coastal zones}

The Asian tsunami, which occurred on Boxing Day, 2004, devastated the coastal regions of several countries, including Indonesia (Sumatra), Thailand (Phuket), Sri Lanka (Eastern and Southern Provinces) and South India. The very high waves and their turbulence during both the incoming and receding phases imparted extreme drag forces and hydraulic gradients on the coastal sandy soils that contributed to significant soil loss as well as piping of fine sands in various areas. In Sri Lanka, the transported fine marine sediments mixed with the surface soils under the turbulent conditions of the tsunami waters, and upon receding settled in a relatively loose state compared with the originally compacted surface densities. Rail tracks built on sandy soils were totally uplifted in some areas as the formation soils were softened or scoured, and the heavier railway ballast sank into the 'slurried' sand beneath the track. Fig. 23 shows the cone penetration test with pore pressure measurement (CPTU) results conducted by the first author near a damaged railway track on a site where over 1500 people lost their lives. The first $500 \mathrm{~mm}$ of the deposits show greatly reduced strength due to the considerable disturbance. Fig. 24 shows a comparison of the particle size distribution curves of the surface sand deposits in two nearby areas where the relatively undisturbed uniform soil was protected behind buildings. The mixing of surface sands with sediments and debris has resulted in a less uniform soil re-deposited in a relatively loose state (void ratio $=0 \cdot 7)$.

Reconstruction of the rail track requires compaction of the surface soils by vibratory rollers and/or dynamic compaction, which is currently ongoing in some places. The void ratio will need to be reduced to at least $0 \cdot 4-0 \cdot 45$ to achieve an adequately stiff surface layer prior to placing the ballast and sub-ballast. Moreover, the operation of trains at the normal speeds exceeding $70-80 \mathrm{~km} / \mathrm{h}$ will also require a more resilient track. The use of geogrids at the bottom of the ballast layer is highly desirable under these conditions, because of the inhomogeneously mixed soils along the track, even within short distances. It is hoped that the use of geogrids will reduce differential settlements of the track and increase the overall resilient modulus of the layered stratum, where the surface soil properties of the disturbed ground may be both variable and unpredictable even after compaction along the track. 


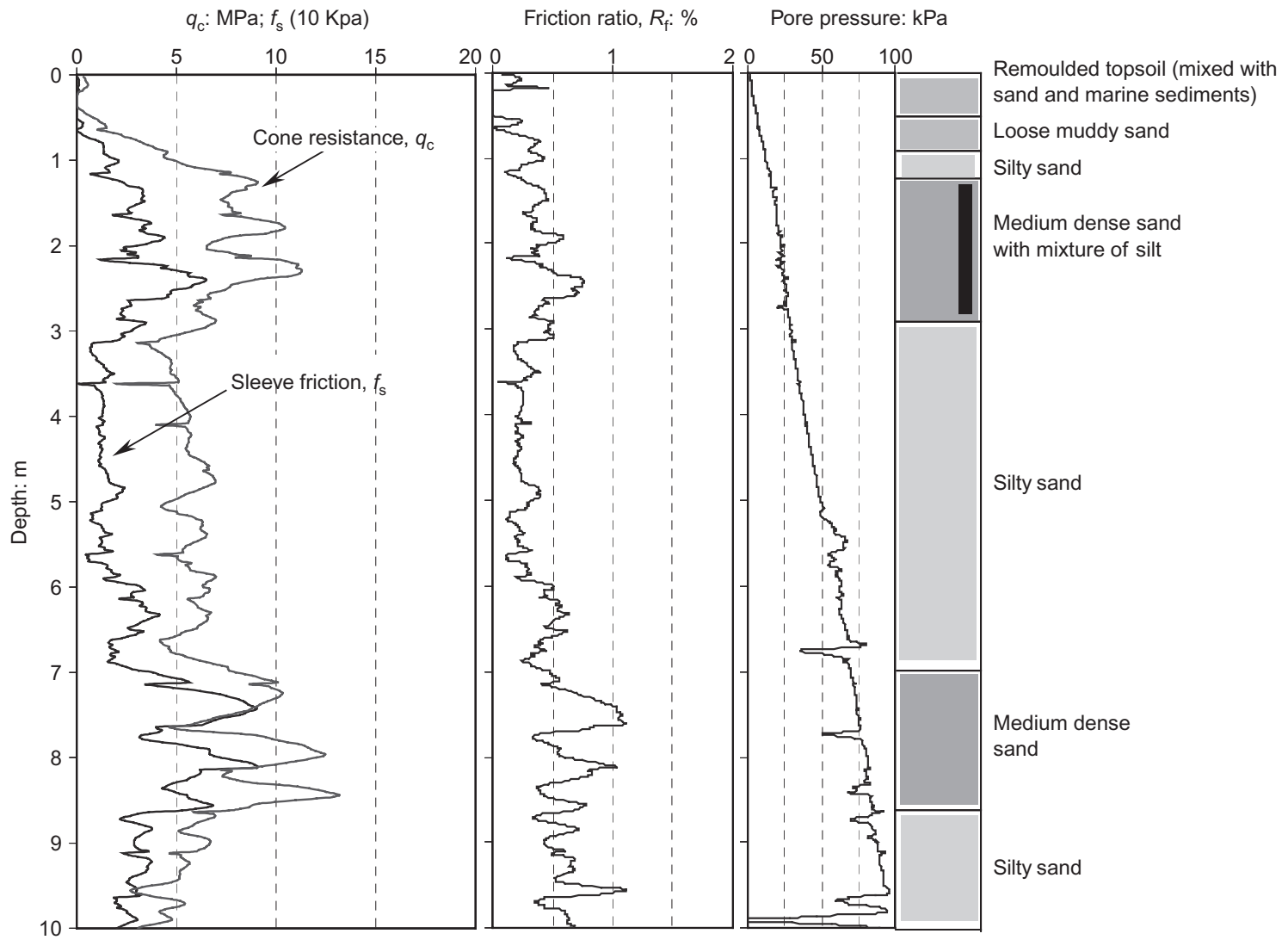

Fig. 23. CPTU test results of tsunami-affected soils

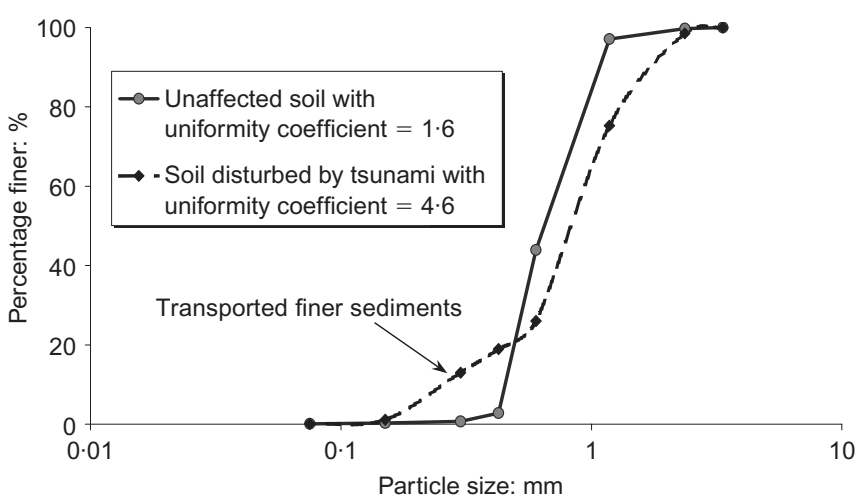

Fig. 24. Particle size distribution curves of tsunami-affected and unaffected soils

\section{Conclusions}

This study highlights the effectiveness of various geosynthetics for stabilising ballasted railway track substructure and formation. The research findings of this study indicate that placing a geosynthetic layer (geogrids, geotextiles or geocomposites) in fresh and recycled ballast decreases settlement and degradation of the tracks. The study indicates that the deformation of fresh and recycled ballast varies non-linearly with the number of load cycles, and that the recycled ballast produces higher settlement than fresh ballast under identical loading and boundary conditions. Saturation of recycled ballast also increases its deformation characteristics. Irrespective of the type of ballast (fresh or recycled), ballast reinforcement (geogrids, geotextiles or geocomposites) and saturation (dry or wet), the settlement of ballast stabilises within about 100000 load cycles. Although the experimental results of this study showed clearly that the extent of degradation and settlement in fresh and recycled ballast was reduced significantly with the insertion of any type of selected geosynthetics, it is strongly recommended that a bonded geosynthetic (geocomposite) is used, because of the need to prevent the ingress of liquefied mud into ballast voids under cyclic loads, as well as to maintain an efficient pore pressure dissipation layer. According to the research results of this study, the inclusion of geocomposites (geogrid-geotextile combination) in recycled ballast decreases the vertical settlement to even less than that of the fresh ballast (without geosynthetics) and decreases the breakage index to be almost equal to that of fresh ballast. In addition, the inclusion of geocomposites in recycled ballast also decreases the lateral strains to a value less than that of the fresh ballast. These results have significant implications for the maintenance cycles of rail tracks and consequently for the cost of the track maintenance. The decrease of ballast vertical settlement and breakage minimises the need for ballast replacement during maintenance, and the reduction of ballast lateral movement decreases the need for crib and shoulder ballast replacement: hence, the track will benefit from minimum confinement. The results of the plane-strain finite element numerical modelling also indicate that the optimum location of geosynthetics for improving rail track deformation may be taken to be $200 \mathrm{~mm}$ beneath the sleeper, considering that a minimum depth of ballast of $150 \mathrm{~mm}$ beneath the sleeper has to be left without geosynthetics, to allow for tamping. However, if the design-required thickness of ballast is more than $200 \mathrm{~mm}$, it will be more 
convenient to place the geosynthetics at the bottom of the ballast bed (i.e. at the ballast/capping interface), to allow for maintenance requirements (e.g. ballast cleaning). Given the proven functions of geocomposites in ballast reinforcement, separation and drainage (filtration), it is expected that Australian railways will adopt such modernisation in the future design of ballast tracks. It is also discussed that prefabricated vertical drains (PVDs) can be used when accelerated rate of consolidation and improvement of soft formation of rail track is desired. However, the factors influencing the performance of PVDs, and particularly the disturbance of soil surrounding the drains due to the installation process, should be considered in design and practice procedures.

\section{Acknowledgements}

The authors express their sincere gratitude to the Cooperative Research Centre for Railway Engineering and Technologies (Rail-CRC), RailCorp (Sydney), and related geosynthetics companies in Australia for their support and cooperation. The authors also express their special thanks to Dr Hadi Khabbaz and Ms Joanne Lackenby for their assistance and contribution to the research project of this paper.

\section{References}

Ashriz E. S., Diederich R. and KoslowsKi C. (2002) The use of spunbonded geotextile in railway track renewal on the St Petersburg-Moscow line, Proceedings of the 7th International Conference on Geosynthetics, Nice, 14-19.

Bergado D. T., Asakami H., Alfaro M. C. and Balasubramaniam A. S. (1991) A smear effect of vertical drains on soft Bangkok clay. Journal of Geotechnical Engineering, ASCE, 117, No. 10, $1509-1530$.

Charles J. A. and Watts K. S. (1980) The influence of confining pressure on the shear strength of compacted rockfill. Géotechnique, 30, No. 4, 353-367.

Hardin B. O. (1985) Crushing of soil particles. Journal of Geotechnical Engineering, ASCE, 111, No. 10, 1177-1192.

Hazen A. (1930) Water supply. In American Civil Engineers' Handbook (ed. Merriman T.) John Wiley, New York.

Holtz R. D., Shang J. Q. and Bergado D. T. (2001) Soil improvement. In Geotechnical and Geoenvironmental Engineering Handbook, (ed. R. Kerry Rowe) Kluwer Academic Publishers, Boston, pp. $429-462$.

InDRARATNA B. and BAMUNAwita C. (2002) Soft clay stabilization by mandrel driven geosynthetic vertical drains. Australian Geomechanics, 37, No. 5, 57-86.

IndRARATNA B. and ReDANA I. W. (1999) Settlement prediction of embankments stabilised with prefabricated vertical drains at 2nd Bangkok International Airport. Proceedings of the 12th European Conference on Soil Mechanics and Geotechnical Engineering, Amsterdam, 1505-1511

INDRARATNA B. and REDANA I. W. (2000) Numerical modeling of vertical drains with smear and well resistance installed in soft clay. Canadian Geotechnical Journal, 37, No. 1, 132-145.

IndRARATNA B. and SAlim W. (2002) Modeling of particle breakage of coarse aggregates incorporating strength and dilatancy. Proceedings of the Institution of Civil Engineers: Geotechnical Engineering, 155, No. 4, 243-252.

InDRARATNA B. and SALim W. (2003) Deformation and degradation mechanics of recycled ballast stabilised with geosynthetics. Soils and Foundations, 43, No. 4, 35-46.

INDRARATNA B., WIJEWARDENA L. S. S. and BALASUBRAMANIAM A. S. (1993) Large-scale testing of greywake rockfill. Géotechnique, 43, No. $1,37-51$
INDRARATNA B., IONESCU D. and Christie D. (1998) Shear behaviour of railway ballast based on large-scale triaxial tests. Journal of Geotechnical and Geoenvironmental Engineering, ASCE, 124, No. 5, 439-449.

IndRaratna B., Ionescu D. and Christie D. (2000) State-of-the-art large scale testing of ballast. Proceedings of CORE 2000, Railway Technology for the 21st Century, Adelaide, pp. 24-1-24-13.

Indraratna B., SAlim W., Ionescu D. and Christie D. (2001) Stress-strain and degradation behaviour of railway ballast under static and dynamic loading, based on large-scale triaxial testing, Proceedings of the 15th International Conference of Soil Mechanics and Geotechnical Engineering, Istanbul, pp. 2093-2096.

IndraRATNA B., Salim W. and Christie D. (2002) Improvement of recycled ballast using geosynthetics. Proceedings of the 7 th International Conference on Geosynthetics, Nice, 20-29.

Indraratna B., Khabbaz H., Salim W. and Christie D. (2003) Geotechnical characteristics of railway ballast and the role of geosynthetics in minimising ballast degradation and track deformation. Proceedings of RAILTECH 2003: Railway Technology in the New Millennium, Kuala Lumpur, pp. 1-22.

Indraratna B., Khabbaz H., Salim W., Lackenby J. and Christie D. (2004) Ballast characteristics and the effects of geosynthetics on rail track deformation. Proceedings of the International Conference on Geosynthetics and Geoenvironmental Engineering, ICGGE, Bombay, pp. 3-12.

IndraRatna B., Lackenby J. and Christie D. (2005) Effect of confining pressure on the degradation of ballast under cyclic loading. Géotechnique, 55, No. 4, 325-328.

Janardhanam R. and Desai C. S. (1983) Three dimensional testing and modeling of ballast. Journal of Geotechnical Engineering, ASCE, 109, No. 6, 783-797.

JefFs T. and Marich S. (1987) Ballast characteristics in the laboratory. Proceedings of the Conference on Railway Engineering, Perth, pp. 141-147.

Lade P. V., Yamamuro J. A. and Bopp P. A. (1996) Significance of particle crushing in granular materials. Journal of Geotechnical Engineering, ASCE, 122, No. 4, 309-316.

Lee K. L. and Farhoomand I. (1967) Compressibility and crushing of granular soil in anisotropic triaxial compression. Canadian Geotechnical Journal, 4, No. 1, 68-86.

Leslie D. D. (1975) Shear strength of rockfill. South Pacific Division Corps of Engineering Laboratory, California, Physical Properties of Engineering Study No. 526.

Marachi N. D., Chan C. K. and Seed H. B. (1972) Evaluation of properties of rockfill materials. Journal of Soil Mechanics and Foundation Engineers Division, ASCE, 98, No. 1, 95-114

MARSAL R. J. (1967) Large scale testing of rockfill materials. Journal of Soil Mechanics and Foundation Engineering, ASCE, 93, No. SM2, 27-43.

MARSAL R. J. (1973) Mechanical properties of rockfill. In Embankment Dam Engineering. John Wiley, New York

Miura N. and O'Hara S. (1979) Particle crushing of decomposed granite soil under shear stresses. Soils and Foundations, 19, No. 3, $1-14$.

Nakata Y., Hyde A. F. L., Hyodo M. and Murata H. (1999) A probabilistic approach to sand particle crushing in the triaxial test. Géotechnique, 49, No. 5, 567-583.

NeIDHART T. (2001) True-to-scale in situ tests determining dynamic performance of earthworks under high speed train loading. Proceedings of Geotechnics for Roads, Rail Tracks and Earth Structures, ISSMGE, Rotterdam, Vol. ETC11, pp. 213-223.

Plaxis B. V. (2004) PLAXIS 2D Version 8·2: Finite Element Code for Soil and Rock Analysis. A. A. Balkema, Delft.

RAmamurthy T. (2001) Shear strength response of some geological materials in triaxial compression. Journal of Rock Mechanics and Mining Sciences, 38, No. 5, 683-697.

RAYMOND G. P. (1985) Research on railroad ballast specification and evaluation. Track Design and Construction: Transportation Research Record, 1006, 1-8.

RAYMOND G. P. (1999) Railway rehabilitation geotextiles. Journal of Geotextiles and Geomembranes, 17, No. 4, 213-230.

Raymond G. P. (2002) Reinforced ballast behaviour subjected to repeated load. Journal of Geotextiles and Geomembranes, 20, No. 1, $39-61$.

Rowe P. K. and Jones C. J. F. P. (2000) Geosynthetics: innovative materials and rational design, Proceedings of GEOENG 2000, Melbourne, 1, 1124-1156. 
SAlim W. (2004) Deformation and Degradation Aspects of Ballast and the Role of Geosynthetics in Track Stabilisation. PhD thesis, Department of Civil Engineering, University of Wollongong, Australia.

SAlim W. and Indraratna B. (2004) A new elasto-plastic constitutive model for granular aggregates incorporating particle breakage. Canadian Geotechnical Journal, 41, No. 4, 657-671.

SElig E. T. and WATERS J. M. (1994) Track Geotechnology and Substructure Management. Thomas Telford, London.
Standards Australia (1996) Aggregates and Rock for Engineering Purposes. Part 7: Railway Ballast. Standards Australia, Sydney, AS $2758 \cdot 7$.

Discussion contributions on this paper should reach the editor by 2 July 2007 